\title{
Yesus Kristus Menurut Orang Papua
}

\author{
Yohanes Kayame a,1 \\ Program Magister Teologi Universitas Sanata Dharma, Yogyakarta ${ }^{a}$ \\ jhonkayame5@gmail.com ${ }^{1}$
}

Keywords:

Kebudayaan

Melanesian Papua,

Kristologi,

Papua,

Asia,

Yesus Kakak,

Pembebas.

\begin{abstract}
This article is pertained to the Papuan Christology that has so far been developed. The writer attempts to reflect and study it based on the Asian Christology. The fundamental question of this study is: "Who do you say I am?" (cf. Mat 16:15-16)". In answering this question, the Papuan Christology becomes the first main point, namely cultural reflection on the concept of salvation and Papuan Christology. The second main point of discussion is that missionary preaching leads Papuans to interpret the western Christology in prayer and liturgy. Based on the analysis of Papuan culture, a number of titles are given to Jesus. From the reciprocal influence between the traditional religion of Papuans about salvation and the missionary preaching on Christian faith the Papuan Christology was born. The present Papuan context requires the study of Christology to respond to the third world challenge. The human right violations in Papua, for instance, is an apparent problem. Thus, a critical study on the Asian Christology has become considerably important. The present synthesis of the Papuan Christology is Jesus the Big Brother Almighty. Jesus Christ was "born" in Papua as He was born from God the Father all centuries before Him, and due to His Resurrection bound by no time and space as well as His Incarnation as a "Human". Jesus as the Big Brother of Papuans fights for some of His Father's missions in Papua, one of which is that He is sent as a Liberator.
\end{abstract}

\section{PENDAHULUAN}

Peter C. Phan, teolog Asia asal Vietnam di USA, mengeksplorasi empat Kristologi Asia yang menurutnya sangat relevan untuk konteks Asia. Phan menunjukkan bahwa empat Kristologi itu merupakan kajian Kristologi kontekstual oleh para teolog Asia untuk mengembangkan teologi berdasarkan konteks dan persoalan Asia. ${ }^{1}$ Pendekatan Kristologi yang dikembangkan di Asia adalah pendekatan "Kristologi dari bawah"; bukanlah pendekatan "Kristologi dari atas". ${ }^{2}$ Titik tolak Kristologi berpangkal dari kehidupan Yesus dalam realitas aktual, praksis hidup. ${ }^{3}$ Distingsi ini menunjukkan bahwa kajian teologi Asia berangkat dari ortopraksis, yakni praksis hidup, dan tidak bertolak dari ortodoksi, yakni: dogma dan Magisterium Gereja. Beberapa teolog Asia menimba inspirasi 
dari Teologi Pembebasan Amerika Latin dan mengembangkannya bertolak dari realitas Asia. Aloysius Pieris, antara lain, mengembangkan sebuah Teologi Pembebasan Asia, di mana sintesis Kristologinya bermuara "dalam Yordan agama Asia" dan "dalam Kalvari kemiskinan Asia" ${ }^{4}$, dan teolog Indonesia, Y.B. Banawiratma, menulis konsep Yesus menurut orang Indonesia, yakni Yesus Sang Guru. ${ }^{5}$ Dasar teologinya adalah inkarnasi Kristus ${ }^{6}$ dalam berbagai budaya di dunia, di mana Ia mengalami penderitaan yang berpuncak pada kebangkitan-Nya, dan menganugerahkan buahnya.

Peter C. Phan di akhir tulisannya tentang Kristologi, mengusulkan agar teolog Asia membuat Kristologi Asia, antara lain: Yesus Kristus sebagai guru, Yesus sebagai kakak, Yesus sebagai mesias hitam dan seterusnya. ${ }^{7}$ Berdasarkan inspirasi Kristologi Asia ini, penulis hendak menggali dan merefleksikan Kristologi Papua-Melanesia, yang dikembangkan oleh beberapa tokoh, secara khusus Yesus dalam budaya Mee. Titik tolak Kristologi Papua adalah pertanyaan Yesus: "Menurut kamu siapakah Aku ini" (Mat 16: 14-16). ${ }^{8}$

Namun, beberapa pertanyaan awal penulis adalah: bagaimana gambaran agama-agama asli Papua-Melanesia, dan bagaimana gambaran awal masyarakat $\mathrm{Pa}$ pua-Melanesia tentang Yesus? Bagaimana mereka mengimani dan menggelari Yesus, baik dalam doa maupun dalam hidup hariannya? Tujuanya agar pembaca mengetahui Kristologi Papua yang dikembangkan sejauh ini dan perluya suatu Kristologi bertolak dari konteks Papua sekarang.

\section{AGAMA DAN KEBUDAYAAN MELANESIA-PAPUA}

Kajian Kristologi Papua tak terlepas dari paham tentang konsep keselamatan dalam pandangan agama-agama tradisional orang Papua-Melanesia. Mereka menghidupi agama tradisional sebelum Injil diwartakan oleh misionaris. Darrell Whiteman, sebagaimana ditulis oleh Agus Alue Alua, merumuskan sebelas ciri penting yang terdapat pada agama dan kebudayaan orang Melanesia di Bumi Papua. ${ }^{9}$

Ciri pertama adalah epistemologi dalam pemikiran Melanesia. ${ }^{10}$ Epistemologi yang dimaksudkan adalah pengetahuan orang Melanesia tentang dunia spiritual dan material atau dunia sakral dan sekular. Keduanya tak terpisahkan dan merupakan bagian integral dalam agama-agama tradisional yang mesti diketahui dan dijaga oleh orang Melanesia. ${ }^{11}$

Ciri kedua adalah pandangan orang Melanesia tentang kosmologi. ${ }^{12}$ Pandangan dunia yang dimaksudkan adalah pada dua dunia, yakni: dunia empiris yang berkaitan dengan lingkungan alam dan sumbersumber ekonomi, serta dunia non empiris pada roh-roh, kekuatan ilmu gaib, dan totem. Kedua dunia ini saling melengkapi dan menjadi bagian integral dalam seluruh kehidupan orang Melanesia.

Ciri ketiga adalah nilai-nilai bagi orang Melanesia. ${ }^{13}$ Nilai-nilai yang dimaksudkan adalah kelangsungan hidup, perlindungan atas hidup, pemeliharaan hidup dan perayaan atas hidup dalam agama Melanesia. ${ }^{14}$ Orang Melanesia menghidupi nilai-nilai ini dalam 
seluruh dimensi kehidupan mereka. Misalnya dalam suku Mee nilai dasariah adalah saling menghormati (ipaa akagatai).

Ciri keempat adalah agama yang dinamis dalam agama-agama Melanesia. ${ }^{15}$ Agama tradisional Melanesia dapat menyesuaikan diri dengan perubahan-perubahan yang terjadi akibat kontak dengan dunia luar. Hal ini antara lain tampak dalam bentuk permohonan yang diungkapkan dalam doa-doa adat. Misalnya doa mohon kesuburan tanah atas kebun yang hendak dikerjakan, seperti ritus emo meeni dalam suku Mee.

Ciri kelima adalah agama-agama Melanesia berorientasi pada kelimpahan hidup. ${ }^{16}$ Artinya, segala sesuatu dilakukan dalam hidup ini agar bermakna dan berkelimpahan (abundant life). ${ }^{17}$ Kehidupan yang bermakna harus dialami mesti hanya berdampak kinisini, bukan di masa depan. Jika di masa kini suatu keluarga belum sejahtera, maka keluarga ini dianggap belum mengalami kelimpahan hidup.

Ciri keenam adalah pentingnya ritual yang mujarab. ${ }^{18}$ Melalui ritual ini ditegaskan kaitan antara obyek yang kelihatan, seperti kebun, orang sakit dan lain-lain dengan sumber hidup yang tak kelihatan, seperti kekuatan daya dan keberuntungan. Kedua obyek ini merupakan kesatuan yang integral; ritual dan doa barulah bersifat mendalam hubungannya dan menjadi bermakna kalau mencakup kedua obyek ini.

Ciri ketujuh adalah pentingnya kerahasiaan. ${ }^{19}$ Kerahasiaan yang dimaksudkan adalah hal-hal sakral, misalnya: mantra berburu, berkebun, dan berperang, yang tidak bisa diceriterakan kepada orang lain di luar suku atau bahkan kepada sesama anggota dalam satu suku. Semuanya harus dijaga kerahasiaan supaya kekuatannya tidak luntur.
Ciri kedelapan adalah kepercayaan pada para leluhur dalam agama-agama Melanesia. ${ }^{20}$ Para leluhur perlu dihormati dan dihadirkan dalam agama tradisional oleh orang Melanesia. Para leluhur ini diyakini ada bersama mereka. Oleh karena itu, hubungan dengannya harus dijaga dan harmonis. Dalam agama tradisional, leluhur adalah bagian yang tak terpisahkan dengan orang yang masih hidup. ${ }^{21}$

Ciri kesembilan adalah orang Melanesia percaya pada roh-roh imanen. ${ }^{22}$ Orang Melanesia meyakini roh-roh imanen telah menciptakan alam dan ada bersamanya. Mereka adalah bagian dari komunitas dan tak terpisahkan dengan orang yang sudah meninggal maupun yang masih hidup. ${ }^{23}$ Oleh karena itu, relasi dengan roh-roh imanen perlu dijaga dan dipulihkan apabila retak, antara lain melalui ritus tertentu demi terpeliharanya hubungan harmoni antara keduanya.

Ciri kesepuluh adalah pentingnya prinsip resiproksitas. ${ }^{24}$ Prinsip ini antara lain tampak dalam kegiatan tukar-menukar barang (gift-exchange). ${ }^{25}$ Resiproksitas dalam tukar-menukar barang mengungkapkan nilai kebersamaan dan persatuan di antara mereka. Pemberi barang pasti akan di ingat oleh penerima, demikian pun sebaliknya, sehingga tercipta kekerabatan dan kesejahteraan hidup.

Ciri kesebelas adalah agama-agama Melanesia tidak bersifat misioner. ${ }^{26}$ Agama tradisional Melanesia dirahasiakan hanya dalam kelompok suku-suku saja. Agama ini bukan untuk diwartakan ke luar sebagaimana agama Kristiani, namun berlaku hanya bagi masing-masing suku. Oleh karena itu, sesuatu yang bersifat rahasia tidak diwartakan kepada keluarga, kepada klan, suku, apalagi kepada suku- 
suku tetangga. Misalnya kata-kata tertentu dalam ritus adat tentang rekonsiliasi (kamu tai) suku Mee tidak boleh diberitahukan kepada orang di luar suku, kepada suku MoniMigani misalnya.

Dalam agama tradisional masyarakat $\mathrm{Pa}$ pua-Melanesia diajarkan bahwa norma-norma perlu dipegang demi hidup yang baik. Norma-norma ini diwariskan oleh leluhur secara turun-temurun ${ }^{27}$. Nilai-nilai yang terkandung di dalamnya mirip dengan Sepuluh Perintah Allah. Misalnya, norma dalam budaya Mee mengajarkan larangan mencuri (oma teyamoti). ${ }^{28}$ Tujuan dari nilai-nilai tersebut adalah agar orang Papua mengalami keselamatan. Keselamatan yang dimaksudkan adalah keselamatan kini-sini; tetap membangun relasi yang baik dengan alam, leluhur atau roh-roh, hidup yang melimpah, terhindar dari penyakit dan kematian. Jika orang Papua meninggal sebelum usia tua, maka relasi dengan beberapa aspek tersebut perlu dipulihkan, karena orang tersebut diyakini belum mengalami keselamatan. ${ }^{29}$ Agama tradisional dan nilai-nilai budaya tersebut merupakan kerangka acuan (frame of reference ${ }^{30}$ ) orang Papua-Melanesia sebelum kontak dengan dunia luar.

\section{GAMBARAN AWAL KEKRISTENAN DI PAPUA}

Agama Kristiani dibawa ke Papua bersama dengan peradaban Barat tahun 1888. ${ }^{31}$ Bersama kaum kolonial, agama Protestan memasuki Papua, tepatnya melalui bagian barat Pulau New Guinea di Mansinam, Manokwari. Sedangkan penyebaran agama Katolik bermula di Fak-Fak dan wilayah selatan Papua. ${ }^{32}$ Oleh karena itu, penduduk asli awalnya menganggap agama Kristiani sebagai "agama penjajah". ${ }^{33}$ Orang-orang lokal pada umumnya melihat bahwa Kristen identik dengan imperialisme Barat. Mereka memandangnya demikian karena para misionaris mula-mula hadir dalam situasi perang, dan dalam pewartaannya tidak mengedepankan kontekstualisasi. Misionaris ibaratnya "mencangkok" agama Kristiani pada budaya setempat daripada melakukan inkulturasi. Oleh karena itu, agama Kristiani diidentifikasi sebagai "agama orang kulit putih" dan "agama kaum kolonialis". ${ }^{34}$

Pada awal masa evangelisasi di Papua, para misionaris umumnya kurang mempelajari budaya dan agama tradisional PapuaMelanesia. Dengan begitu mereka tidak melihat bahwa agama tradisional orang Papua itu cukup kaya akan nilai-nilai Kristiani. Baru sejak tahun 1960-an ada misionaris yang memberi perhatian kepada bidang antropologi dan etnologi, seperti misalnya: Jan Boelaars MSC, Herman Peters OFM, Alfons van Nunen OFM, dan Sibele Hylkema OFM. Mereka mulai mengusahakan inkulturasi iman Kristiani ke dalam budaya setempat. ${ }^{35}$ Namun menurut J. Gaquare, dalam mewartakan iman banyak misionaris kurang memperhatikan nilai-nilai budaya yang ada pada masyarakat setempat. Menurutnya, diperlukan adanya suatu pendekatan Teologi Kristiani yang mempribumi ${ }^{36}$ yang memungkinkan Injil diterima dan dipahami orang Melanesia sebagai kabar gembira keselamatan kini-sini.

Dalam merumuskan konsep tentang Kristus-Melanesia, teolog Papua-Melanesia bertolak dari para teolog Amerika Latin. ${ }^{37}$ Mereka berteologi bahwa Kristus di Amerika Latin adalah Kristus berkulit hitam. ${ }^{38}$ Teologi mereka tentang Yesus berkulit hitam awalnya ditentang oleh para teolog Eropa karena bertentangan dengan identitas Yesus yang sebenarnya, artinya Yesus historis. ${ }^{39}$ Namun argumentasi teologis para teolog Amerika 
Latin tentang inkarnasi dan kebangkitan Yesus membuka cakrawala secara inter-kontinental, untuk memahami kehadiran-Nya dalam berbagai budaya, termasuk sukusuku di Oceania. ${ }^{40}$ Kristologi kontekstual yang dikembangkan tersebut merupakan refleksi iman atas praksis dalam terang Injil Yesus Kristus.

Dalam pengembangan artikel ini, menurut penulis perlu dalam "rambu" Kristologi Kontekstual, dan benarlah apa yang dikatakan oleh Anton Wessels:

"Yesus Kristus tetap sama dari dahulu, kini dan sepanjang segala masa. Dia yang telah ada sebelum Abraham ada (Yoh 8:58), Ia tetap sama, baik kemarin maupun hari ini atau esok (Ibr 13:18), Ia adalah Firman Allah dan menjadi manusia (Yoh 1:14). Dialah juga yang melanjutkan pekerjaan-Nya hari ini“. ${ }^{41}$

Pokok-pokok selanjutnya adalah gambaran Yesus Kristus yang diimani dalam konteks Papua pada umumnya, dan dalam konteks suku Mee pada khususnya.

\section{YESUS KRISTUS DI PAPUA}

Kajian Kristologi Papua tentunya tak terpisahkan dari kajian Soteriologi. ${ }^{42}$ Yang dimaksudkan dengan Soteriologi di sini adalah gambaran tentang keselamatan orang Papua yang telah diuraikan sebelumnya. Kajian Soteriologi Papua berkenaan dengan mitos-mitos Papua. Mitos pada masing-masing budaya Papua mengisahkan tentang keselamatan. Dalam sejumlah mitos muncul tokoh-tokoh tertentu yang diyakini sebagai penyelamat. Suku-suku yang bersangkutan condong mengidentikkan ciri-corak tokoh mitosnya itu dengan ciri "Yesus Sang Penyelamat". Penyamaan seperti itu terjadi, mi- salnya: dalam suku Muyu-Mandobo dengan mitos Kamberap, dalam suku Hubula Wamena dengan mitos Naruekul, dalam suku Mee-Paniai, dengan mitos Koyeidaba, dan dalam suku Moni-Migani dengan Peagabega. Beberapa "figur penyelamat" ini hidup dalam mitologi Papua- agama tradisional Papua sebelum Yesus Kristus diperkenalkan oleh misionaris.

Pandangan orang Papua tentang Yesus berwajah Papua antara lain tampak dalam mitos-mitos ini. Kehidupan para tokoh dalam mitos sangatlah ajaib; berbeda dengan kehidupan orang lain dalam suku. Sebagaimana di Papua, begitu pula di seluruh benua Asia, mitos-mitos atau ceritera rakyat adalah sumber Asia untuk refleksi teologi Kristen. Tentang hal ini, Peter C. Phan mengatakan:

"Sumber kelima Asia adalah budaya Asia pada umumnya, yang terdapat dalam sejumlah ceritera rakyat, mitos-mitos, simbol, puisi, sejumlah lagu, seni visual dan tari-tarian. Semuanya adalah sumber khas Asia untuk refleksi teologis. Beberapa penggunaan artefak budaya yang menjanjikan tentu menyumbangkan suara khas Asia untuk teologi Kristen, yang merupakan kerinduan terdalam masyarakat Asia”. ${ }^{43}$

Begitu pula di Papua, mitos-mitos merupakan salah satu sumber lokal dan sarana untuk mengimani Yesus.

Pewartaan misionaris membantu orang Papua berefleksi tentang Yesus. Iman terdalam orang Papua terhadap Yesus diungkapkan dalam liturgi dan doa harian mereka. Dalam doa, mereka mengungkapkan siapa itu Yesus secara turun-temurun hingga kini. Banyak gelar terhadap Yesus, berdasarkan pengalaman suka-duka hidup mereka, di- 
ungkapkan dalam budaya orang Papua. Baik paham keselamatan dalam agama-agama Melanesia maupun iman kepada Yesus berkat pewartaan misionaris tentu turut mempengaruhi Kristologi Papua sejauh ini.

\section{Yesus Kristus Berwajah Suku Moni-Migani}

Suku Migani adalah salah satu suku di Pegunungan Papua yang berdomisili di Kabupaten Intan Jaya. Sebagaimana sukusuku lain di Papua, suku ini tidak mengenal dunia luar sebelum kontak dengan para misionaris dan pemerintah. Orang Migani pertama dapat mengenal dunia luar melalui pewartaan misionaris, baik oleh misi maupun Zending. Misionaris Katolik pertama di suku Migani ialah Pater Godfried Misael Kammerer OFM tahun 1952. ${ }^{44}$ Misionaris Protestan pertama ialah Pendeta Bill Cutts dan istrinya Ny. Gracy Cutts tahun 1954-1955. Kedua misionaris (Kammerer dan Bill) serta para pengikutnya memberikan dampak positif dalam memperkenalkan dunia luar, terutama dalam memperkenalkan dan mengakarkan iman akan Yesus dalam wilayah Intan Jaya. Sebelum kontak dengan agama, orang Migani mempunyai kepercayaan terhadap alam dan leluhur. Mereka meyakini adanya "Sang Pencipta", yang telah menciptakan manusia Migani maupun alam wilayah Migani. Orang Migani menyebutnya Emo, yang artinya Sang Pencipta. Emo dipuji dan diagungkan dalam ritus dan doa adat mereka. Refleksi iman orang Migani tentang Yesus Kristus sebagai Peagabega dan sebagai I Aina kami rangkum sebagai berikut.

Refleksi kristologis pertama adalah Yesus Peagabega. Pewartaan para misionaris mengantar suku ini pada sebuah refleksi tentang Allah dan Tuhan Yesus. Orang Migani merefleksikan bahwa kehadiran Yesus dan karya-Nya identik dengan seorang tokoh dalam mitos suku Migani, yakni kehadiran dan kehidupan tokoh Peagabega. Kehidupan Peagabega diceriterakan turun-temurun oleh leluhur suku ini. ${ }^{45}$ Dia dilahirkan dan dibesarkan dalam suatu keluarga sederhana. Ayah dan ibunya bernama Ogakendo dan Kalibagabu. Kehadirannya dalam keluarga serta perkembangan hidup dan karya Peagabega membawa berkat-melimpah bagi keluarga dan manusia Migani. Namun sebagian anggota klan memusuhi Peagabega meskipun kehadirannya telah membawa keselamatan. Ia dimusuhi karena sesama sekitarnya iri atas beberapa keajaiban yang dilakukannya. Akhirnya ia ditikam, dibunuh dengan panah serta dimakamkan di usia muda. Namun pada hari ketiga, ia bangkit atau hidup kembali. Dalam tubuh Peagabega, mengalirlah darah, nanah, dan lemak; di tempat ia dimakamkan mengalir pula tiga sungai. Tiga sungai ini hingga sekarang diyakini masyarakat Migani bersumber dari darah, nanah dan lemak Peagabega, untuk kehidupan orang Migani. ${ }^{46}$

Kehadiran Gereja di Migani membantu masyarakat setempat menggali kembali nilai-nilai positif dalam kebudayaan mereka. Kehadiran Peagabega merupakan salah satu tokoh mitologis dalam sejarah kehidupan Migani. Ia memiliki karakteristik antara manusiawi dan adi-manusiawi; ia bukanlah manusia Migani biasa. Ia memberi keselamatan dengan cara memberi umur panjang, memberi kesuburan, mencegah berbagai kejahatan, kematian dan berbagai bencana alam. Orang Migani melihat adanya beberapa kemiripan dengan kehidupan Yesus dan Peagabega. Misalnya, kepala Yesus dimahkotai duri dan kedua kaki dan tanganNya ditembusi paku, Ia ditombak di bagian lambung-Nya. Pada tubuh Peagabega, rotan besar dililitkan di kepalanya, dan tubuhnya ditancap dengan sejumlah anak-panah. ${ }^{47}$ 
Bagaimana kontekstualisasi Yesus Peagabega dalam masyarakat Migani? Dalam drama kisah sengsara Jumat Agung, Peagabega ditampilkan sebagai sosok Yesus dalam konteks penderitaan dan kematian versi kematian Yesus Peagabega. Seorang pemuda yang memanggul salib berperan menampilkan kisah hidup Yesus Peagabega. Kisah penderitaan dan kematian Yesus di Golgota disintesis dengan sengsara dan kematian tokoh ini. Ia disalibkan, dan kepalanya diikat dengan rotan-berduri dan dibunuh dengan panah Migani-Papua. Dalam drama penyaliban Yesus di puncak Golgota-Migani, mereka mengikuti empat belas perhentian. ${ }^{48}$

Sosok Yesus Kristus Peagabega adalah Yesus orang Nazaret yang sudah bersama orang Migani dan memberikan kehidupan manusia dan alam Intan Jaya. Yesus Nazaret yang dinamakan Yesus Kristus Peagabega memanggil orang berdosa, menguatkan kaum lemah, menyembuhkan orang sakit, memberikan umur panjang, memperdamaikan yang bermusuhan, baik dalam keluarga maupun klan, memberikan kehidupan dan keselamatan suku Migani dan suku-suku lain. Refleksi atas misi Yesus ini tentu didasarkan pada buah penyaliban Yesus (Rm 8: 31-39) dan kebangkitan-Nya (ay. 39).

Refleksi kristologis kedua dari suku ini adalah Yesus Kristus I Aina. Orang Migani, berkat pewartaan misionaris, merefleksikan Yesus sebagai I Aina. Dalam budaya Migani, sosok $i$ aina adalah kakak pertama dalam keluarga, klan dan marga. Ia memiliki peranan pertama dan utama dalam suku Migani. Oleh karena itu, sebutan $i$ aina dikenakan kepada Yesus Kristus sebagai kakak yang senantiasa bersama orang Migani. Penghormatan terhadap Yesus sangat me- nonjol karena siapa pun orang Migani, entah tua maupun muda, akan menyapa Yesus Kristus sebagai I Aina atau Kakak Kami. ${ }^{49}$

Refleksi iman orang Migani atas Yesus hendak menunjukkan bahwa Yesus Kristus sebagai Putra Allah (Emoju) bukan tokoh yang biasa seperti mereka. Yesus dipandang sebagai I Aina justru karena Dia adalah Allah sang Pencipta yang turun menjadi manusia sama seperti orang Migani kecuali bahwa Ia tidak berbuat dosa. Oleh karena itu, setiap masyarakat Migani, tua maupun muda, akan menyebut Yesus Kristus adalah Kakak yang menjadi tokoh panutan dan teladan hidup bagi masyarakat wilayah ini. Dia dapat menuntun mereka mengalami keharmonisan, kedamaian, kebahagiaan dan keselamatan. Buah Yesus Kristus I Aina ini diyakini bukan hanya dalam keluarga dan klan, tetapi I Aina dalam konteks alam semesta (kosmik). Yesus Kristus I Aina memperdamaikan dan menyatukan segala sesuatu di dalam diri-Nya (Kol 1: 15-20).

\section{Yesus Kristus Berwajah Suku Hubula-Wamena}

Suku Hubula adalah salah satu suku di Lembah Balim, Wamena. Mayoritas orang Hubula beragama Protestan dan Katolik. Misionaris Katolik masuk di wilayah ini tahun 1954. Para misionaris membaptis umat, melestarikan pelayanan kepada umat, serta membangun sejumlah karya pastoral. Dibantu oleh pewarta atau prodiakon (wenewolok dalam bahasa suku Hubula), para misionaris berusaha, dalam bimbingan Roh, membuat iman Kristiani berurat berakar dalam hati jemaat setempat. Iman kepada Yesus diungkapkan dalam bahasa daerah. Mereka mengimani bahwa Yesus adalah sumber segala-galanya yang baik.

Suku ini mempunyai beberapa konsep tentang Yesus Kristus. Konsep itu bertolak 
dari refleksi tentang pengalaman iman dalam kehidupan mereka dan dari refleksi terhadap seorang tokoh mitos penyelamat, yakni Naruekul, seorang yang mirip dengan tokoh Peagabega pada masyarakat Migani. Selain itu, refleksi Kristologi pada suku Hubula tampak dari tiga gelar Yesus orang Hubula.

Refleksi kristologis pertama adalah Yesus Kristus Naruekul. Orang tua suku Hubula sampai saat ini meyakini bahwa Naruekul sangat relevan dengan kehidupan Yesus dan demikian pula sebaliknya. Keyakinan mereka ini, menurut orang luar Hubula atau intelektual tidaklah masuk akal. Namun, faktanya orang Hubula selalu menghubungkan kisah sengsara dan kebangkitan Yesus Kristus dengan peristiwa pembunuhan Naruekul. ${ }^{50}$ Pola dan gaya sederhana orang Huwula untuk mengerti dan memahami Naruekul adalah sama dengan kisah tentang peristiwa Yesus.

Yesus, dalam perjamuan malam terakhir bersama murid-Nya, membagi roti dan anggur sebagai tubuh dan darah-Nya. Yesus dibunuh dan mati di kayu salib. Seluruh hidup-Nya sampai dengan pencurahan darah-Nya telah menyelamatkan manusia. Naruekul dibunuh oleh orang sekitarnya, dan potongan-potongan tubuhnya diambil oleh masing-masing klan; ada yang mengambil dagingnya, rambutnya, gumpalan darahnya, tulang, kuku, jantungnya dan sebagainya. Masih ada kemiripan lain antara kisah sengsara Yesus dengan kisah Naruekul. Setelah wafat dan dimakamkan, Yesus bangkit dari antara orang mati pada hari yang ketiga. Sementara tokoh Naruekul muncul kembali beberapa hari kemudian dengan posisi tubuhnya yang utuh. Saat Naruekul kembali dengan tubuh yang prima, orangorang sekitarnya heran dan bertanya-tanya: orang ini sudah dibunuh namun hidup kembali dengan utuh. ${ }^{51}$

Penghayatan orang Hubula terhadap Naruekul mengingatkan, dan mempermudah mereka untuk melihat figur Yesus, Orang Nazaret. Berdasarkan pertemuan Injil dan budaya, umat Hubula menyebut Yesus Naruekul. Yesus adalah keturunan Daud, namun melalui inkarnasi, sudah ada dalam budaya Hubula. Ia tetap menyertai umat-Nya dalam suka dan duka, dalam setiap pekerjaan; Ia dapat menyembuhkan orang sakit. Ia adalah panutan atau pemimpin, dan pemberi keselamatan definitif sebagaimana dinubuatkan oleh para nabi (Yes 53: 5; Ibr 4: 14-16; 5: 7-9).

Refleksi kristologis kedua suku ini adalah Yesus Kristus Ninoe. Dalam budaya Hubula terdapat ungkapan Yesus Ninoe. Kata ninoe terdiri dari dua kata, yakni nit yang berarti kita, dan noe, yang berarti kakak saya, yang lebih tua dan sulung. An berarti aku, sedangkan noe artinya kakak saya. Maka kata ninoe atau annoe berarti kakakku atau kakak kita. Kata ini bukan hanya mengandung arti genealogis, melainkan mengandung arti lebih luas. Dalam konteks keluarga dan klan, kata ini dikenakan kepada seorang yang dituakan. Menyebut seseorang ninoe, berarti memandangnya sebagai penyelamat bagi adik-adik, dan panutan dalam keluarga besar dan komunitas. Orang Balim menyebut Yesus Ninoe, karena peranan-Nya sebagai seorang kakak dalam struktur adat maupun dalam penyelamatan dari kesesakan. Orang Balim merasa bahwa mereka adalah adikadik (nagaromi) yang membutuhkan tuntunan, perhatian dan kasih dari kakaknya. Yesus lebih dulu hadir; Ia lebih dulu menyapa orang Balim. Ia dipandang jauh lebih kuat dan tahu segalanya tentang suku ini. 
Orang Hubula dalam doa selalu mengawali dengan Allah Ninopase, yakni: Allah Bapa kita dan Yesus Ninoe, yang artinya Kakak Yesus, Saudara atau Sahabat kita. Gereja mewartakan kepada orang Hubula bahwa Yesus adalah Anak Allah (Allah Abut). Oleh karena itu, orang Hubula merasa dirinya sebagai adik-adik atau sahabat Yesus. Logika penghayatan orang Hubula, yaitu Allah adalah Bapa, Yesus adalah Putra-Nya dan orang Hubula adalah saudara-saudara-Nya. ${ }^{52}$ Ada pula iman suku Hubula kepada Roh Kebenaran yang senantiasa berkarya. Dengan demikian, aspek trinitas dihayati pula oleh suku ini. Namun Yesus sebagai Ninoe (Kakak) adalah ungkapan iman orang Hubula terhadap Yesus Sang Kristus, yang pertama diciptakan berkat kebangkitan-Nya .

Markus Haluk, dalam refleksi kristologi dalam suku Hubula, menyatakan bahwa:

"Orang Balim menyebut Yesus sebagai Ninoe pertama-pertama adalah Yesus sebagai ciptaan, Manusia Pertama yang hadir lebih dahulu bila dibandingkan dengan manusia Balim. Sebagai Anak Pertama dari manusia dan segala ciptaan, Ia mengetahui lebih banyak; lagi pula lebih menguasai manusia, alam serta segala jenis tumbuhan yang ada di bumi. Dia menguasai dan mengatur segalanya". ${ }^{53}$

Dengan kata lain, Yesus-lah kekekalan: "Akulah Alpha dan Omega, yang pertama dan yang terakhir, permulaan dan akhir" (Why 11: 8). Yesus Ninoe adalah asal dan akhir kehidupan manusia. Dialah yang ada, yang sudah ada, dan yang akan datang (ay. 18). Dengan demikian, Yesus Ninoe yang adalah Alpha dan Omega mengabulkan serta memberikan petunjuk bagi agaromiNya atau adik-adik-Nya.
Refleksi kristologis ketiga adalah Yesus Ap Kain. Mengapa orang Hubula di Balim menyebut Yesus sebagai Ap Kain? Orang Hubula sering menyebut Yesus hewe ap kain, artinya Yesus, Engkau pemimpin besar kami. Kata $A p$ artinya bapak, pria perkasa, berwibawa. Kata kain artinya pemimpin. Dengan demikian, ap kain berarti pria berwibawa, pria pemimpin perkasa, pemimpin hebat. Dari pemahaman ini, orang Huwula merefleksikan sosok Yesus dengan kuasa-Nya melakukan banyak mukjizat sehingga dipandang hebat dan berwibawa dalam perbuatan maupun perkataan-Nya. ${ }^{54}$ Dalam pengertian umum, orang Baliem, yang suka menolong dan membantu, dan memahami disebut sebagai ap kain. Kain dikenakan pada hampir setiap tingkatan usia. Kain dikenakan pula kepada sosok yang sungguh berbuat baik, entah anak laki-laki maupun perempuan. Pribadi tersebut adalah orang yang senantiasa menuruti nasehat orang tua, entah suami maupun istri, dan menciptakan keharmonisan dalam keluarga dan dalam relasi dengan keluarga lain, dan dalam satu komunitas (dalam bahasa Hubula adalah honai)..$^{55}$

Konsep kain dikenakan kepada Yesus karena Yesus adalah orang yang baik, mampu membaca suka-duka umat-Nya. Yesus diharapkan hadir dan ada di tengah-tengah mereka. Yesus sebagai Kain hadir memimpin suku ini. Yesus sebagai Kain hadir di tengahtengah masyarakatnya, merangkul dan turut merasakan apa yang mereka alami. Bila situasi kurang menguntungkan, Yesus sebagai Kain tampil untuk membawa berkat bagi mereka. Haluk, dalam refleksinya, mengungkapkan harapan agar orang Balim memiliki sikap Yesus sebagai Kain dalam seluruh hidupnya. Sifat-sifat seorang kain 
yang oleh anggota suku Hubula dilihat ada pada Yesus, dilukiskan Haluk sebagai berikut:

"Ia mesti berbuat secara langsung untuk menjawab dan mengantisipasi apa yang dialami umat Balim. Caranya ialah memberdayakan para pemimpin dengan Roh-Nya dalam mengadakan perencanaan untuk bekerja kebun dan lainnya supaya umat dapat hidup baik ... umat Balim memerlukan sosok pemimpin yang mampu dapat merangkul dan memimpin mereka". ${ }^{56}$

Figur kain itu ada pada sosok Yesus. Yesus Kristus Kain mampu memimpin dan menuntun masyarakat Balim. Yesus Kain mampu memberikan dan mengajarkan kasih akan segala-galanya: kepada Allah, kepada sesama manusia, khususnya kepada orang sengsara dan miskin (Luk 14: 12-14). Ia menghendaki agar orang mengasihi sesama seperti dirinya sendiri (Mat 22: 39). Yesus Kain mengajak supaya ada cinta kasih antara adik-adik (nagoromi), antar anggota keluarga (akhuniekao). Sambil mengasihi sesama (akhonihunikmeke), ajakan Yesus Kain, hendaklah tetap mengasihi Allah (Elalin Walhoak) sebagai sumber kasih.

\section{Yesus Kristus Berwajah Suku Ngalum}

Suku Ngalum mempunyai paham tertentu tentang Yesus Sang Kristus. Suku ini berada di ujung timur Pegunungan $\mathrm{Pa}-$ pua. Misionaris Fransiskan (OFM) mulai menginjakkan kaki dan mewartakan Injil di wilayah suku ini sekitar tahun 1959; sementara pihak Protestan aliran GIDI (Gereja Injili di Indonesia) sekitar tahun 1973. ${ }^{57}$ Umat Katolik, berkat pewartaan para misionaris Fransiskan, mengungkapkan iman mereka akan Yesus melalui doa dan liturgi khas Ngalum.
Salah satu gelar yang menonjol adalah Yesus Kristus sebagai Uropki atau Kakak Laki-laki Pertama. Kata uropki terdiri dari dua kata, yakni urop; artinya kakak pertama, dan ki dikenakan kepada laki-laki. Jadi uropki adalah kakak laki-laki sulung dan tertua. Uropki sangat berperan dalam budaya Ngalum, baik dalam keluarga maupun komunitas yang lebih besar. Karena dia lakilaki pertama dan sulung dalam keluarga, ia diberi kepercayaan dan hak penuh oleh orang tuanya untuk memperhatikan adik-adiknya, terutama dalam mengatur dan membagi warisan keluarga. Seorang uropki mesti melaksanakan apa yang diwariskan oleh botom (bapak) kepada ningbel-bebyel (adikadik) dan mabil-bebyel (keluarga). Uropki sangat berperan pula dalam kehidupan keluarga lain, dan klan-klan dalam suku Ngalum. ${ }^{58}$

Orang Ngalum mengidentifikasi Yesus sebagai Uropki atau Anak Pertama; dalam arti bahwa Ia Kakak untuk keluarga, untuk klan dan untuk seluruh suku Ngalum. Ia berasal dari Allah, Bapa-Nya (Atangki). Ia adalah Manusia Pertama, menurut orang Ngalum; dilahirkan bagi dunia dan keluarga serta komunitas suku Ngalum. Dia diberi kepercayaan dari Atangki untuk misi menyelamatkan manusia Ngalum. Ia bersama-sama dengan Allah menciptakan alam Aplim-Apom atau Negeri Pegunungan Bintang. Ia adalah pewarta Sabda kebenaran atau Allah wenga. Ia diyakini bersama orang Ngalum; memberikan kehidupan sejak semula, yaitu ketika alam dan suku Ngalum diciptakan. Dia, sebagai Kakak Pertama, dapat memberikan rekonsiliasi bagi Negeri Aplim Apom, dan orang yang berdiam di dalamnya, serta semua negeri lainnya. Kehidupan damai dengan sesama, alam dan hidup berlimpah hanya terjadi dalam diri Yesus Uropki. Dialah permulaan, 
dan memperdamaikan segala sesuatu, baik yang ada di bumi maupun yang ada di surga melalui darah-Nya di salib (lih. Kol 1: 1520). Segala sesuatu diciptakan di dalam Dia dan diperdamaikan dalam Dia. Masyarakat Ngalum memohon kepada Yesus Uropki, agar terhindar dari kelaparan, konflik, segala jenis penyakit, dan peperangan yang menimbulkan perpecahan.

\section{Yesus Kristus dalam Pandangan Orang Mee (Mee-uwo) Papua}

Sebelum membahas gambaran suku Mee tentang Yesus Kristus secara lebih terperinci sebagai sebuah kristologi Papua, akan dipaparkan informasi mengenai suku Mee. Suku Mee secara geografis berada di bagian barat wilayah Pegunungan Papua. Sebutan nama Mee pertama-tama muncul dari suku Mee sendiri. ${ }^{59}$ Sebutan lain diberikan pula oleh suku-suku sekitarnya. ${ }^{60}$ Namun nama Mee merupakan sebutan yang erat kaitannya dengan sifat dan karakter orang Mee, baik pengetahuan, sikap, ketrampilan dan falsafah orang Mee. Jika orang Mee mewujudkan sikap dan perbuatannya sesuai nilai dan norma (touyemana), maka mereka pantas disebut sebagai orang Mee, artinya manusia sejati.

Orang Mee mempunyai mata pencaharian berladang dan beternak. ${ }^{61}$ Mereka juga mempunyai struktur organisasi sosial, baik dalam perkawinan maupun dalam kepemimpinan. Mereka memiliki agama tradisional dengan kepercayaan akan adanya Pencipta (Ugatame). Agama tradisional suku ini telah mengakar dalam masyarakat Mee sebelum agama Kristen diwartakan. Mereka berusaha agar relasi dengan sesama, dengan alam, dengan leluhur, dan terlebih dengan Ugatame senantiasa dijaga agar tetap harmonis.

Orang Mee meyakini bahwa Ugatame sudah ada dalam budaya Mee sebelum In- jil diwartakan. Dia sebagai Pencipta dan Pelindung. Mereka merefleksikan Ugatame hadir dan membimbing dalam perjalanan hidupnya. Neles Tebay, berkenaan dengan gagasan tersebut, menekankan:

\begin{abstract}
"Israel sebagai contoh bahwa Allah hadir dalam dunia. Kitab Suci Perjanjian Baru mewartakan bagaimana Allah menghadirkan Yesus secara penuh. Yesus menghadirkan Allah, oleh karena itu, diri-Nya menjadi barometer kehadiran Allah. Hal ini juga mau menunjukkan bahwa sesungguhnya Yesus juga sebelumnya telah ada sebelum misionaris datang. Allah tidak pernah diimpor. Misionaris tidak pernah membawa Allah ke Tanah Papua". ${ }^{62}$
\end{abstract}

Ungkapan Tebay mengandung makna bahwa misionaris meneguhkan kehadiranNya di Tanah Papua; mereka mengartikulasi apa yang sudah hadir di Tanah Papua walau belum terumus dengan terperinci. Roh Kudus telah berkarya lebih dulu dalam diri orang Papua. Orang Mee sudah menyebut Allah sebagai Pencipta Manusia (Ugatamee), Manusia di Atas (Wadomee), Manusia Ajaib (Poyamee), dan Bapa Kita (Initai).

Orang Mee, sebagaimana suku-suku lain, benar-benar mengimani Yesus. Mereka mengenal-Nya lebih mendalam berkat pewartaan para misionaris, misalnya melalui Injil Mee Mana, yakni terjemahan Injil dalam bahasa Mee yang telah berhasil dikerjakan pada tahun 1980-an. Mereka sungguh menghayati Yesus sebagai bagian dari kehidupan, bahkan Ia sebagai pusat kehidupan Mee. Orang Paniai-Mee menerapkan gelar-gelar kepada Yesus, karena mereka percaya akan Yesus orang Nazaret yang telah bangkit, dan sebagai Tuhan Mulia sudah ada dalam budaya, alam dan manusia Mee. Melalui refleksi inkarnasi Kristus, 
orang Mee mengidentifikasikan Yesus dalam arti bahwa mereka tahu siapakah Yesus itu dengan bantuan kisah seorang tokoh Koyei$d a b a$, tokoh penyelamat dalam mitos orang Mee.

Orang Mee, setelah Injil diwartakan, mengenakan gelar-gelar kepada Yesus sambil bertolak dari pengalaman eksistensial dan realita hidup mereka kini. Masyarakat Mee meyakini bahwa Yesus secara nyata ada dalam seluruh kehidupannya, baik dalam suka maupun dalam duka, baik dalam untung maupun malang. Orang Mee menghayati bahwa Yesus dapat berperan mengubah hidup lama yang penuh gejolak menjadi baru dalam Dia. Mereka mengungkapkannya dalam doa-doa serta lagu-lagu bahasa Mee. ${ }^{63}$

Koyeidaba telah diyakini masyarakat Mee sebagai penyelamat mereka, sebelum Yesus diwartakan di wilayah Mee. Penulis mengangkat pula tokoh ini agar orang Mee mengimani Yesus melalui kehadiran Koyeidaba dan menghayati nilai-nilai yang diwariskannya. Setelah itu, penulis membahas pula tentang siapa Yesus menurut orang Mee, yakni pusat dan sumber bagi orang Mee pada khususnya dan bagi orang Papua serta non Papua pada umumnya.

\section{Kepercayaan Orang Mee akan Yesus Kristus via Koyeidaba}

Orang Mee mengidentifikasi Yesus dengan bantuan suatu mitos, yakni hikayat Koyeidaba. Sebagaimana dapat diperbuat terhadap pelbagai tokoh mitos di Papua, berikut ini penulis mengadakan refleksi kristologis-soteriologis atas kehidupan tokoh Koyeidaba. Menurut orang Mee, kehidupan Koyeidaba itu mirip dengan hidup Yesus. Kisahnya sangat menarik, mulai dari kelahiran sampai kematian. Namun demikian kemiripan dengan Yesus orang Nazaret bukan dalam segala hal. Nilai-nilai budaya yang diwariskan bersangkut-paut dengan peranannya, misalnya: Koyeidaba sebagai pemberi hidup; Koyeidaba sebagai pewaris nilai-nilai budaya suku Mee (Touyemana atau Totamana); dan Koyeidaba sebagai pemberi keselamatan. ${ }^{64}$

Pertama adalah peran Koyeidaba sebagai pemberi makanan kehidupan. Koyeidaba telah memproduksikan makanan dan telah memberikan kehidupan bagi keluarga dan warga sekitarnya selama musim kelaparan melanda wilayah Mee. Kehadirannya telah mengubah kehidupan yang lapar dan miskin menjadi kehidupan yang berlimpah-ruah. Keluarga asal dan sekitarnya yang dilanda kelaparan memperoleh makanan, menjadi sehat dan bisa beraktivitas. Mereka mengalami dan merasakan apa yang dikatakan orang Mee sebagai mobu, artinya mengalami kepenuhan hidup kini-sini. Namun Koyeidaba menyampaikan kepada kelompok yang membenci dan membunuhnya bahwa kehidupan mereka itu tidak akan mengalami mobu (keselamatan). Orang-orang yang membenci Koyeidaba merasa iri karena sikapnya yang baik terhadap warga Mee dan sekitarnya. Pihak yang mengutuknya, tidak melihat kehadiran dia sebagai "Yesus" yang memberikan hidup. Mereka tidak melihat kehadirannya sebagai pemenuhan hidup yang akan dimulai dari keluarga, klan dan seterusnya. ${ }^{65}$ Koyeidaba dibunuh ketika masih berusia muda.

Makanan yang dihasilkan telah membawa kehidupan, tidak hanya untuk keluarga dan klan sekitarnya, tetapi bahkan untuk semua klan suku Mee. Koyeidaba memberikan makanan yang cukup, dan dapat membagikannya kepada yang lain walaupun tidak sama berlimpah dengan yang dialami keluarga asal. Berkaitan dengan makanan ini, 
orang Mee mengaitkan Koyeidaba dengan Yesus yang memberikan makanan bagi 5000 orang.

Koyeidaba, selain memproduksi makanan dan menghadirkan keselamatan bagi orang Mee, juga membawa pedoman hidup atau Totamana manusia Mee. Pedoman hidup itu telah diwariskan oleh nenek moyang orang Mee, namun dibawa dalam bentuk buku oleh Koyeidaba. Dalam narasi mitos Koyeidaba dikatakan tentang ajarannya yang dimuat dalam buku kehidupan totamana. ${ }^{66}$ Koyeidaba tidak mewartakan ajaran tersebut, karena dia dibunuh pada usia muda. Namun, bukunya disimpan oleh ketiga saudari Koyeidaba. Buku tersebut hingga kini tidak diketahui keberadaannya. Orang Mee hanya meyakini bahwa Totamana atau Touyemana adalah nilai-nilai budaya Mee yang diwariskan turun-temurun. ${ }^{67}$ Ajaran ini, akhirnya menjadi pedoman atau frame of reference dalam suku ini. Orang Mee merefleksikan bahwa Yesus mewartakan tentang Sabda Tuhan dan ajarannya dimuat dalam Injil. Orang Mee menyebut pula Injil sebagai Touyemana (bahasa Mee: Injil Touyemana) dan mengajarkan tentang hidup baik; salah satunya adalah cinta kasih atau ipa-akagatai sebagai hukum pertama dan utama umat Kristen.

Selanjutnya adalah Koyeidaba sebagai Pemberi Keselamatan. Bentuk-bentuk keselamatan orang Mee adalah tidak terjadi kegersangan, hidup damai, bersatu, tenang, tidak ada kelaparan, kemiskinan dan penderitaan, tetap tercipta relasi yang harmoni, tidak ada kematian sebelum usia tua. Orang harus mengalami keselamatan pada saat kini-sini; bukan keselamatan yang dinantikan kelak (wiyaume atau emino). Koyeidaba telah membawa keselamatan itu: keselamatan dari kemiskinan dan ke- laparan. Keluarga Koyeidaba dan sekitarnya tidak meninggal akibat kelaparan; mereka hidup berkelimpahan, dan mengalami keselamatan. ${ }^{68}$

Hidup berkelimpahan orang Mee merupakan impian Koyeidaba. Orang Mee harus mengalami aji (keselamatan), dan mobu (hidup berkelimpahan). Mereka harus berada di dalam situasi syalom. Kehadiran Koyeidaba memberikan harapan hidup orang Mee dari musibah kelaparan ini. Tubuh Koyeidaba dipotong-potong dan dimakan oleh orang yang membunuhnya. Sangat aneh, namun ajaib, bahwa tidak ada musim kelaparan setelah ia dibunuh. Menurut refleksi lebih jauh oleh orang Mee berkenaan dengan Koyeidaba, pengorbanan Kristus di salib membawa keselamatan bagi banyak orang, bukan hanya kini melainkan juga yang akan datang. Demikian pun Tubuh dan Darah Yesus diberikan untuk keselamatan dan persekutuan lebih dalam dengan-Nya.

Sebagai kesimpulan, orang Mee memandang Yesus Kristus dengan Koyeidaba sebagai latar belakang; bukan berarti bahwa Koyeidaba itu Yesusnya orang Mee. Tetapi kehidupan Koyeidaba adalah mirip dengan kehidupan Yesus. Berkat pewartaan para misionaris, orang Mee diantar untuk melihat kembali kehidupan tokoh ini. Orang Mee kadang menyebut Yesus Kristus Koyeidaba sambil mengintegrasi karya Yesus Nazaret dengan kehidupan Koyeidaba. Beberapa ungkapan iman suku Mee dapat disintesis sebagai berikut: Yesus Koyeidaba sebagai Pemberi Hidup orang Mee; Yesus Koyeidaba sebagai Pembawa Sabda Allah (Totamana); dan Yesus Koyeidaba sebagai Pemberi Keselamatan, terutama berupa iman, melalui pengurbanan-Nya di puncak Golgota. 


\section{Yesus Kristus Ugatame Yokaibo}

Orang Mee menyapa Allah sebagai Ugatame. Kata Ugatame berasal dari dua kata, yakni ugata dan me. Ugata berarti Yang Menciptakan, dan me berarti manusia. Jadi Ugatame berarti Pencipta Manusia. Ugatame tentu juga menciptakan kosmos dan manusia; Dia adalah "Tuhan semesta alam" (lih. Am 4: 13). Sedangkan yoka berarti seorang anak laki-laki. Ibo berarti besar, agung, tunggal.

Dalam pengertian orang Mee, Ugatame Yokaiibo adalah Anak Allah yang besar, pertama dan utama atau maha besar. Dengan demikian, orang Mee diyakini sebagai adik-adiknya Yesus dan sekaligus sebagai anak-anak Allah. Ia adalah Manusia dari Allah. Ia telah menjadi manusia, dan melaluiNya penciptaan baru terlaksana bagi manusia dan alam ciptaan-Nya. Semuanya dari Allah diwariskan kepada dan melalui Ugatame Yokaibo.

Orang Mee, lebih banyak menggunakan ungkapan Ugatame Yokaibo dalam doa dan liturgi. Mereka mengungkapkan gelar Ugatame Yokaibo karena Ia ada di atas bumi, dan telah menjadi manusia, Ia ada sejak pra-eksistensi dunia dan telah hadir pula antara manusia. Oleh karena itu, kekuatan surgawi dilimpahkan melalui-Nya. Segala rahmat Allah diberikan dengan pengantaraan Yesus Kristus Ugatame Yokaibo. Ia selalu ada untuk memberikan kehidupan ketika masyarakat mengalami kelaparan berkepanjangan; memberikan keselamatan; Ia menciptakan harmoni, kehidupan yang tenteram dan damai. Ugatame Yokaibo dapat melindungi dan menyembuhkan segala macam penyakit. Ia memelihara alam serta manusia yang telah diciptakan agar tetap baru dalam diri-Nya.

\section{Yesus Kristus Iniuwai Ibo}

Selain melihat Yesus sebagai Ugatame Yokaibo (Anak Allah yang Maha Besar) masyarakat Mee memakai juga gelar Iniuwai Ibo untuk Yesus. Gelar ini terdiri dari dua kata, yakni iniuwai, yang artinya kakak kami; dan ibo berarti besar atau maha agung. Dengan demikian, Yesus Iniuwai Ibo adalah Yesus Kakak Besar Kami. Gelar yang se-arti adalah kakak sulung atau wauwa. Kata wauwa adalah suatu kata yang diperuntukkan bagi anak pertama laki-laki dalam keluarga. Dalam budaya Mee, seorang wauwa diharapkan memiliki karakteristik positif seorang bapak. Wauwa diyakini akan meneruskan warisan keluarga untuk selamanya. Namun anak kedua dan ketiga juga diharapkan akan ikut memelihara dan menghidupi karakteristik orang tua mereka. ${ }^{69}$

Konsep wauwa berlaku dalam kehidupan bermasyarakat. Dalam masyarakat terdapat orang yang sangat berpengaruh dan berperan sentral. Orang yang demikian dihormati sebagai seorang wauwa, artinya sebagai kakak besar dan tertua dalam masyarakat Mee. Dalam budaya suku ini, seorang wauwa atau iniuwai memiliki enam karakteristik dasar: sehat, kaya, murah hati, istimewa dalam debat publik, berani dan penebus. Dengan demikian, seorang wauwa adalah pembawa mobu (keselamatan). Selain enam karakteristik ini, wauwa atau iniuwai adalah orang yang mampu berpegang pada dimi (pemikiran) orang Mee. Ia dapat lalui tahapan melihat (dou), berpikir (gai) dan bertindak (ekowai)..$^{70}$

Orang Kristen Mee menyebut Yesus sebagai Iniuwai Ibo di dalam doa-doa yang bersifat liturgis. Dia bukanlah sekedar 
Wauwa (Kakak), namun lebih dari itu Ia adalah Iniuwai Ibo atau Nauwai Ibo (Kakak Maha Besar Kita). Ia adalah sumber dou (dalam melihat), sumber gai (berpikir) dan sumber ekowai (tindakan). Sebutan Iniuwai Ibo ini menyatakan bahwa Yesus yang berasal dari Allah menyingkapkan diriNya dalam kehidupan konkrit manusia Mee sebagai Iniuwai Ibo. Dia adalah Kakak yang memberikan petunjuk, menjadi teladan, memberikan ketenangan, kepuasan, keamanan, keselamatan, kebahagiaan, dan pengampunan. Ia memberikan perhatian dan kebahagiaan kepada kaum lemah, yang sedang menderita, papa miskin dan lain sebagainya. Jadi, Yesus Iniuwai Ibo adalah Yesus yang all-inclusive love. ${ }^{71}$ Yesus Iniuwai Ibo rela menderita dan berkorban bagi banyak orang, bukan hanya bagi satu suku dan budaya saja.

Yesus Iniuwai Ibo yang bangkit memberikan harapan bahwa akan ada suatu hidup baru bagi yang lemah, miskin, disiksa, dihina, dibantai dan dibunuh. Sejumlah pergumulan, persoalan, suka dan duka, kelaparan, sakit dan derita, melalui Yesus yang bangkit, diubah menjadi baru. Yesus Iniuwai Ibo yang adalah juga Pembawa mobu akan membawa orang pada keselamatan. ${ }^{72}$ Orang Mee mengungkapkannya melalui doa kepada Ugatame (Allah) melalui Yesus Iniuwai Ibo, yang mencintai segala suku bangsa.

\section{Yesus Kristus Meeka-Kabo}

Orang Mee mengungkapkan gelar Yesus Mee-ka Kabo dan Owa Kabo. Istilah Yesus Mee-ka Kabo terdiri dari kata bahasa Mee, yaitu: Mee, yang berarti orang atau manusia; ka menunjukkan kepunyaan; dan kabo artinya dasar atau pondasi. Istilah Yesus Mee-ka Kabo berarti Yesus sebagai dasar atau pondasi. Jadi, istilah Yesus Mee-ka Kabo adalah keyakinan orang Mee terhadap Yesus, yang adalah dasar atau pondasi kehidupan manusia Mee.

Mengapa orang Kristen Mee menyebut Yesus sebagai Mee-ka Kabo? Dalam budaya Mee, orang yang membangun rumah adat atau ema-owa dan lain sebagainya pasti membutuhkan kayu besi yang kuat dan bertahan selama bertahun-tahun. Bagi Orang Mee sebuah rumah membutuhkan dasar atau kabo yang kuat sebagai landasan yang kokoh. Hal itu diungkapkan dalam sebuah ritus orang Mee. Yesus menjadi pondasi kehidupan orang Mee kini-sini. Yesus dilihat juga sebagai kabo abadi yang menjamin berdirinya kokoh kuat untuk menghadapi berbagai masalah dan pergumulan hidup. ${ }^{73}$

Dalam seluruh kehidupan, bahaya dapat mengancam selalu, bukan hanya pada hari yang malang, tetapi juga pada hari yang untung. Selain itu, kehidupan orang Mee banyak mengalami kesusahan yang berkepanjangan, entah dalam keluarga, entah dalam kampung. Orang Mee juga merasakan bahwa adakalanya kehidupan mereka kacau balau karena ulah dari antara mereka sendiri. Ada orang meninggal karena relasi yang kurang baik dengan alam, leluhur dan sesama. Akibat relasi yang kurang baik, maka terjadi kematian. Kematian ini, menurut pemahaman orang Mee, diakibatkan oleh ulah orang lain atau karena relasi yang kurang harmonis dengan alam dan leluhur. Menurut mereka hal ini terjadi karena kabo (fondasi hidup) belum kuat, maka perlu dipulihkan dan dikuatkan kembali. ${ }^{74}$

Tidak ada jalan lain kecuali Yesus memulihkan kabo atas semua persoalan orang Mee. Sebagai orang Kristen, mereka menyampaikan doa permohonan kepada Allah melalui Yesus sebagai Mee-ka Kabo. 
Orang Mee meyakini Yesus sebagai pondasi bersumber dari Allah. Dia adalah Ugatame Yokaibo. Mereka mengimani bahwa Allah sebagai sumber pondasi utama untuk manusia Mee dan dunia. Pondasi itu diletakkan oleh Yesus sejak manusia diciptakan oleh Allah (Ugatame). Atas pondasi itulah orang senantiasa berdiri. Yesus adalah sumber dan dasar itu, karena Dialah Sabda Allah. Orang Mee percaya bahwa Allah melalui Yesus Kristus menjaga, memelihara semua manusia dan menguatkan mereka dalam penderitaan. Yesus diimani sebagai pondasi kehidupan orang Mee. Semua persoalan dan pergumulan disampaikan kepada Yesus sebagai Mee-ka Kabo, pada dasar dan sumber segala kehidupan.

\section{Yesus Kristus Maipaiwiyai}

Refleksi kristologis berikutnya adalah Yesus sebagai Maipaiwiyai. Kata maipaiwiyai terdiri dari dua kata, yakni maipai dan wiyai. Kata maipai artinya selalu menciptakan damai, dan wiyai menunjuk kepada sosok. Dengan demikian, kata maipaiwiyai diterjemahkan sebagai sang pendamai. Mengapa Yesus digelari sebagai Maipaiwiyai? Dalam budaya Mee, nama maipaiwiyai menunjuk kepada orang-orang tertentu yang diberi kharisma oleh Ugatame untuk menyelesaikan masalah di antara pihak-pihak yang bertikai. Orang yang menyelesaikan masalah dan berdoa untuk pemulihan keluarga, marga dan lain sebagainya, dinamakan maipaiwiyai. Maipaiwiyai bisa ditujukan pula kepada kepala suku di kampung, kepala marga, kepala suku Mee di wilayah Paniai (Meeuwodide), kepala suku Mee di luar wilayah Paniai, seperti di Jayapura dan lain sebagainya. Mereka ini mempunyai tanggungjawab untuk menciptakan rekonsiliasi melalui pembicaraan dan kesepakatan bersama apabila ada masalah dan konflik. Keti- ka seorang yang berjiwa maipaiwiyai hadir, maka akan ada rekonsiliasi yang memungkinkan kembalinya syalom. Kepala suku Mee di Jayapura, misalnya, harus melindungi sukunya, dan menjadi maipaiwiyai dalam menangani, menetralisir, dan mendamaikan apabila ada problem. Orang Mee merasa terlindungi apabila sosok maipai selalu ada bersama mereka, sehingga adanya kedamaian lebih terjamin.

Gelar Yesus Maipaiwiyai mendapat arti dan maknanya dalam konteks di atas. Namun kedudukan dan peranan Yesus diyakini orang Mee sebagai lebih tinggi dan lebih luas daripada apa yang menurut pandangan mereka menjadi tugas dan tanggungjawab seorang maipaiwiyai. Yesus sebagai Maipaiwiyai diimani orang Mee sebagai Anak Allah atau Ugatame Yokaibo yang dapat melaksanakan lebih daripada yang dilakukan orang Mee. Ia ada di antara orang Mee dan orang lain dan menjadi Sang Rekonsiliator Utama..$^{75}$

Yesus diimani sebagai Sumber dan Puncak Rekonsiliasi (Maipaiwiyai Bokouto). Ia mengungguli semua maipai yang biasa itu dalam mendamaikan persoalan keluarga, klan, suku serta menguasai setiap situasi dan kondisi, dan memulihkan hubungan yang retak, termasuk relasi dengan alam (bdk. 2 Kor 5: 18-20). Orang Mee bermohon kepada Yesus Maipai untuk meredakan juga gemuruh dan gelombang danau Paniai, danau Tigi, danau Tage di Paniai (Meuwodide), dan danau Sentani di Jayapura, seperti Yesus meredakan gelombang di danau Galilea.

Orang Mee mengarahkan hati kepada-Nya dalam doa dan nyanyian Mee. Mereka menaruh harapan kepada Yesus Maipaiwiyai agar Ia mencurahkan belas kasihan atau ipabokouto. Dalam liturgi Gereja se-dunia, umat bermohon: "Tuhan 
kasihanilah kami"; di sana orang mengalami pengampunan. Berkat pengurbanan-Nya di salib, Yesus sudah bertindak sebagai Maipaiwiyai, mendamaikan hubungan yang retak antara manusia dengan Allah, antara manusia dengan manusia, antara manusia dengan alam. Sama seperti peranan Maipaiwiyai dalam budaya Mee, kegiatan sang Kristus pun tidak terbatas pada konflik keluarga, klan dan suku, tetapi mempunyai dimensi kosmis, sebagaimana ditegaskan A. Sunarko yang merujuk kepada Kol 1: 20 untuk menggarisbawahi perdamaian kosmis dengan perantaraan Kristus: "oleh Dialah (Kristus) Ia (Allah Bapa) memperdamaikan segala sesuatu dengan diri-Nya, baik yang ada di bumi, maupun yang ada di surga, sesudah Ia mengadakan pendamaian oleh darah salib Kristus". ${ }^{76}$

\section{Yesus Kristus Mobubokouto}

Orang Mee mengakui Yesus sebagai Mobubokouto, sebuah gelar yang bernuansa soteriologis. Kata mobubokouto ini terdiri dari dua kata, yaitu mobu artinya, tidak ada kelaparan, tidak ada kemiskinan, tidak ada kematian, dan kata bokouto artinya sumber atau pusat kehidupan. Jadi, Yesus Mobubokouto merupakan Yesus, Sang Sumber Kehidupan. Yesus memberikan kesejahteraan, kesuburan, kemakmuran. Mereka meminta kepada Yesus melalui doa permohonan dan dalam pengurbanan babi agar diberikan pemulihan dan kehidupan baru. Yesus memberkati segala jenis tanaman dan binatang piaraan masyarakat, seperti tanaman nota (ubi), eto (tebu), nomo (keladi), ekina (babi), dan sebagainya.

Mereka mengharapkan agar Yesus senantiasa memberikan mobu (kehidupan/keselamatan). Orang Mee memanjatkan doa, baik secara pribadi maupun dalam ibadah bersama, agar hidup berkelimpahan dapat dirasakan. Iman akan Allah diungkapkan dalam Mee mana (bahasa Mee) sebagai media komunikasi iman. Mereka merenungkan karya-karya keselamatan Allah dalam kebudayaan Mee dengan mengimani secara lebih mendalam Yesus yang diwartakan oleh Gereja. ${ }^{77}$

Dalam Ekaristi, orang Katolik Mee melihat Yesus sebagai Nota ${ }^{78}$ Kehidupan; suatu gelar yang tidak jauh berbeda makna dengan Yesus Mobubokouto. Supaya kenyang dan tetap hidup, mereka harus makan nota setiap hari. Makanan lain, seperti sagu, ubi kayu, dan sejenisnya adalah makanan tambahan; bukan makanan pokok. Yesus sebagai Nota dapat dihubungkan dengan konteks Ekaristi, yakni Yesus sebagai Roti Kehidupan. Yesus menguatkan mereka dengan makan Roti sebagai Tubuh-Nya, yakni Nota; dan minum Anggur sebagai Emo atau darah-Nya. Yesus Mobubokouto secara nyata hadir memberikan Nota, yakni diri-Nya, dan menyatukan seluruh umat-Nya maupun segala sesuatu dalam diri-Nya sebagai Kepala (bdk. Ef 1: 10). Dengan demikian, semuanya berada dalam persekutuan dengan Dia, sehingga senantiasa mengalami kelimpahan hidup. Yesus Mobubokouto mencerminkan Yesus yang memberi makan 5000 orang, dan yang mengadakan perjamuan terakhir bersama kedua belas murid-Nya. Yang telah diperbuat-Nya dahulu di Galilea dan Yudea, sekarang dilakukan-Nya pula untuk keluarga, klan dan komunitas Kristiani suku Mee dan pulau Papua umumnya. Ia menguatkan dan menyatukan semuanya dalam Dia.

\section{Yesus Kristus Ajibokouto}

Orang Kristen Mee mengungkapkan Yesus adalah sumber keselamatan dengan sebutan Ajibokouto. Kata ajibokouto terdiri dari kata aji selamat, syalom; dan kata bokouto, sumber atau pusat keselamatan. 
Yesus Ajibokouto diterjemahkan sebagai Yesus Sang Sumber dan Pusat Keselamatan. Konsep keselamatan orang Mee adalah keselamatan kini dan akhirat. Keselamatan kini adalah orang mengalami mobu sebagaimana yang diuraikan di atas: hidup damai dengan diri, dengan sesama, dan dengan alam. Keselamatan akhirat adalah kehidupan di alam arwah bersama para leluhur dalam perspektif budaya Mee. Jadi, keselamatan orang Papua pada umumnya dan orang Mee pada khususnya harus mengalami keselamatan di dua dunia, yakni di dunia sekarang atau kini-sini dan di akhirat (arwah). Keselamatan kini-sini diharapkan akan terjadi sekarang ini. Oleh karena itu, mereka berusaha dengan berbagai macam cara, termasuk memohonkannya melalui ritus-ritus tertentu, agar orang tetap mengalami aji dan mobu itu. ${ }^{79}$

Yesus Ajibokouto adalah dasar dan sumber keselamatan kekal. Ia melimpahkan keselamatan kini dan kelak (surga). Setelah Injil diwartakan, keselamatan akhirat bagi orang Mee bukan lagi terjadi di dunia arwah, melainkan di surga (Ugatame ya Owapa). Dunia arwah bukanlah obyek yang harus dipuji oleh orang Papua-Mee. Yesus yang pertama bangkit pada hari ketiga itu masuk dalam dunia arwah Mee, memulihkan keadaan mereka, dan mengantarnya pada kehidupan kekal. Keselamatan atau aji adalah buah dari pengorbanan Yesus di puncak Golgota yang sudah tersedia bagi mereka karena kebangkitan-Nya. Oleh karena itu, sejumlah praktek dan ritus adat yang menyangkut kematian dalam budaya orang Mee hampir ditiadakan dan bahkan dimusnahkan, terutama oleh umat Mee yang Protestan. Orang Mee umumnya mempunyai iman yang kuat bahwa Yesus sebagai pusat dan sumber keselamatan (Ajibokouto) sudah menyediakan tempat di surga berkat janji-janji aji yang telah diucapkan-Nya di Yahudi-Palestina. Sebagaimana juga sukusuku lain, orang Mee pun mengungkapkan iman dan harapan akan aji itu melalui tebayam (doa), melalui musik liturgi Mee dalam nyanyian dan tarian, seperti: wani, uga, kotekauga, komauga, dan tupe.

\section{RELEVANSI KRISTOLOGI SUKU MEE DALAM KONTEKS PAPUA}

Gelar-gelar Yesus Kristus, dalam budaya Mee, sangat berpengaruh dalam kehidupan iman masyarakat Mee. Gelar-gelar ini bertolak dari pengalaman hidupnya, yakni nama-nama tertentu dan nilai-nilai tertinggi dalam budaya Mee-Papua. Refleksi Teologi yang dikembangkan adalah inkarnasi Kristus dan kebangkitan mulia Yesus, maka Ia ada di Papua bahkan dalam hati dan pikiran mereka, sehingga Yesus diungkapkan sebagai Dimikabo dan Owa Kabo. Orang Mee menjumpai dan mengalami nilai-nilai budaya dan merefleksikannya dalam terang nilai-nilai Injil yang dihidupi masyarakat Mee.

Misionaris memperkenalkan Yesus, dan mereka mempelajari budaya Mee. Di antara misionaris itu ada yang ahli anthropologi, sehingga inkulturasi Injil dapat diusahakan dengan memperhatikan konteks setempat. Orang Mee diantar untuk berefleksi bahwa Yesus adalah mirip dengan mitos Koyeida$b a$, dan mitos-mitos tertentu dalam beberapa budaya Papua. Namun para misionaris, yang telah mewartakan secara kontekstual, mengantar umat secara lebih mendalam untuk betul-betul mendalami siapa Yesus menurut orang Papua. Berdasarkan kajian ini, orang Papua-Mee dapat mengungkapkan Yesus Sang Kristus, misalnya Yesus Kristus sebagai Iniuwai Ibo (Kakak Besar Kita). 
Refleksi Kristologi Mee ini hendak menggarisbawahi Yesus Iniuwai Ibo sebagai dasar dan pondasi hidup. Dia senantiasa bertindak sebagai Ipabokouto (Sang Belas Kasih), Maipaiwiyai (Sang Rekonsiliator) dan sebagainya. Dia memanggil dan merangkul semua orang, entah siapa pun dia, dari golongan mana pun; Yesus adalah Sang Belas Kasih dan Pemulih bagi semua orang (dalam bahasa Mee; idima bage Ipa Mee $),{ }^{80}$ dan untuk kosmos Papua. Ungkapan orang Mee lainnya terhadap Yesus adalah Yesus Kristus Nauwai (Kakak). Ungkapan, yang maknanya sama adalah Yesus Uropki oleh suku Ngalum, dan Yesus Ninoe oleh suku Hubula, dan Yesus I Aina oleh suku Moni-Migani.

Orang Papua melihat Yesus sebagai Kakak Pertama atau Sulung. Ia memiliki peranan penting dalam keluarga, setiap komunitas klan, setiap marga. Ia adalah Kakak dalam setiap suku di Papua. Jika Yesus digelari sebagai Iniuwai Ibo atas orang $\mathrm{Pa}$ pua dan kosmos Papua, maka Ia mengatur, menuntun dan membimbing mereka. Yesus Ninoe menjadi andalan dalam mengarahkan orang Papua pada norma-norma dan nilainilai yang telah diwariskan. Demikian pun makna yang sama dimiliki oleh gelar Yesus Uropki, yaitu Ia menciptakan keselamatan kini-sini dan keselamatan kelak.

Refleksi teologis tentang gelar Kakak untuk Yesus didasarkan pada misteri iman akan Dia sebagai Sabda dan Putra Allah, Ia lahir dari Bapa sebelum segala abad. Ia menjelma menjadi manusia. Sebagai manusia, Dialah "yang sulung, lebih utama dari segala yang diciptakan" (Kol 1: 15). Di dalam Dia, kita sendiri diangkat Allah menjadi anak-anakNya. Kita sebagai anak angkat, kita menjadi adik-adik Yesus. Maka Yesus menyebut kita saudara-saudara-Nya (Mat 12: 30 dst). Juga karena kebangkitan-Nya, Yesus itu Kakak kita karena Ia yang pertama bangkit dari antara orang mati (Why 1:5).

\section{IMAN ATAS YESUS KRISTUS DALAM KEBUDAYAAN ORANG PAPUA}

Bagi paham mengenai pribadi Yesus dalam budaya-budaya di Papua pentinglah untuk meninjuanya dari sudut pandang Kristologi Asia. Uraian unsur-unsur berkristologi Asia oleh Phan tentu memiliki kesesuaian dan memberi sumbangan bagi upaya menggali paham Yesus dalam budaya Papua. Keempat Kristologi Asia yang dicatat Phan (dalam uraian berikutnya ini) mempunyai relevansi bukan hanya untuk masing-masing budaya Asia yang dibahas Phan, tetapi juga untuk budaya-budaya lainnya di Asia dan malah untuk dunia ketiga seluruhnya.

Yesus Kristus bagi orang Papua dapat mengatasi semua persoalan yang dihadapi orang Papua, oleh karena itu, Ia adalah pusat kehidupan. Berhadapan dengan perkembangan teologi dunia ketiga, maka beberapa gelar terhadap Yesus oleh orang Papua (dalam pembahasan sebelumnya) dapat diintegrasikan secara bersama untuk Kristologi Papua dalam konteks Papua sekarang. Gelar-gelar terhadap Yesus berdasarkan konteks Asia yang dikemukakan Phan adalah Yesus sebagai Biksu Miskin, yaitu citra Yesus yang dikembangkan oleh Aloysius Pieris. Tentang gelar ini, pertama-tama ia bertolak dari konteks kemiskinan dan keagaman Asia, terutama agama Budha sangat berpengaruh kuat di Asia. Maka, Yesus di Asia yang mesti dihayati adalah Yesus Biksu Miskin. Sebagaimana Yesus masuk dalam budaya dan Agama Yahudi melalui ketaatan pada pembaptisan di Sungai Yordan dan penyalibannya di Kalvari, demikian pun Yesus yang masuk dalam konteks Asia dapat membebaskan dua problema Asia (kemis- 
kinan dan keanekaragaman agama Budha ini) dalam "Yordan Agama Asia" dan "Kalvari Kemiskinan Asia”. ${ }^{81}$

Kristologi Asia Joung Young Lee adalah Kristus sebagai Realisasi Perubahan Sempurna dan Yesus-Kristus sebagai Seorang Marginal yang Istimewa. Lee bertolak dari pola Nalar Ying dan Yang dalam teologi perubahan yang menekankan hal yang tetap (absolut) dan dalam keberadaan yang tetap mengalami perubahan (proses). Maka, Yesus Kristus mesti digambarkan sebagai Realisasi Perubahan Sempurna. Allah adalah Pencipta (absolut) dan Kristus adalah bagian dari proses kreaktivitas Ilahi dari Allah. Firman Allah dan Yesus sebagai Firman adalah bagian dari rencana Allah dan daya cipta-Nya. Gelar Kedua adalah Yesus sebagai Orang Marginal yang Istimewa. Lee di Amerika adalah orang yang hidup di Pinggiran. Oleh karenanya, Lee dalam Kristologinya merefleksikan bahwa hampir seluruh kehidupan Yesus berada di pinggiran, namun berkat kebangkitan-Nya, Yesus berada di pusat kehidupan, Yesus menyatukan keduanya (orang di pusat dan pinggiran). ${ }^{82}$

Lantas Yesus dalam konteks kaum tersalib dan Yesus yang senantiasa berkarya dalam kekuasaan Roh adalah Kristologi Asia yang diketengahkan oleh Chaong-Seng Song. Song mendengar secara teologis ceritera masyarakat Asia yang menderita. Maka Song mengungkapkan: Yesus dalam rupa kaum tersalib dengan menunjuk "Allah-Ku, Allah-Ku, mengapa Engkau meninggalkan Aku? Song menegaskan juga identitas Yesus sebenarnya tersingkap dalam perjamuan terakhir, yang dalam konteks Asia adalah perjamuan Masyarakat (meja bundar Cina, simbol persaudaraan). Gelar lain dari Song adalah Yesus dalam Kuasa Roh. Gelar dari Song ini menegaskan kuasa Roh bekerja hingga masa kini dan masa yang akan datang (akhirat). Roh Kudus melingkupi dan melintasi semuanya. ${ }^{83}$

Kristologi Asia tentang Kristus Minjung di dalam Minjung dipaparkan oleh Chung Hyun Kyung. Kyung memulai teologinya dengan mendengarkan ceritera perempuan dengan cermat. Maka Kaum perempuan mesti melihat Yesus sebagai hamba yang menderita, Kristus Tuhan dan Immanuel. Ia berjuang agar perempuan Asia tidak berada di bawah otoritas Gereja, kemiskinan dan penindasan oleh kolonialisme dan neo-kolonialisme, kediktatoran militer dan seluruhnya berada di bawah patriarkat. Oleh karena itu, citra Yesus sebagaimana dilukiskan dalam teologi perempuan Asia, antara lain, adalah Yesus sebagai Pembebas, Tokoh Revolusioner dan Martir Politik. ${ }^{84}$

Julukan yang diberikan kepada Yesus dalam masing-masing budaya Papua haruslah menjadi benih, orientasi embrional dan tahap pendahuluan sebuah Kristologi Papua dalam konteks kini. Belajar dari Kristologi Asia sebagaimana dicatat Phan itu, Kristologi Papua mesti bertolak dari konteks Papua saat ini selain dari pokok-pokok Kristologi Papua di atas. Benih-benih Kristologi Melanesia, dan khususnya Papua, menurut contoh Kristologi Asia, bukan hanya untuk sukusuku tertentu di Papua, misalnya hanya untuk orang Mee, akan tetapi diperuntukkan bagi semua orang. Umpamanya, Yesus sebagai Kakak Pertama Kita (Iniuwai Ibo); makna gelar ini berlaku untuk segala suku bangsa, memiliki karakter Pembebas.

Yesus adalah pemimpin utama bagi orang Papua-Melanesia dan Kakak Utama bagi umat Kristiani seluruh dunia. Yesus Iniuwai Ibo/ Uropki/ Ninoe merangkul dan memulihkan dan memanggil semua orang, entah orang sakit atau lemah, orang terku- 
cil atau terpinggirkan, yatim piatu, kaya, miskin, semua tingkatan usia, setiap suku maupun ras. Karya Yesus ini diungkapkan dalam doa dan musik liturgi beberapa suku Papua, misalnya Mee: Dege bage na Aniya mee, buna bage na Aniya mee, Yesus akiya mana $^{85}$ (Aku, Yesus, menghendaki semua orang menjadi milik-Ku). Dalam kajian pada pokok ini terungkaplah iman dan harapan orang Papua bahwa Kristus menjadi pusat dalam semuanya, dan Ia adalah universal dalam segalanya. Yesus yang diimani oleh orang Papua sejak sediakala itu, dan kini Ia berperan dalam situasi Papua. Ia radikal, dapat membebaskan segala-galanya demi menghadirkan kerajaan Allah.

\section{KESIMPULAN}

Kajian Kristologi Papua yang dikembangkan sejauh ini pertama-tama bertolak dari landasan biblis tentang Inkarnasi Kristus dengan berpangkal pada Injil Keempat: "Firman itu telah menjadi manusia, dan diam di antara kita, dan kita telah melihat kemuliaan-Nya, yakni kemuliaan yang diberikan kepada-Nya sebagai Anak Tunggal Bapa, penuh kasih karunia dan kebenaran" (Yoh 1: 14; Fil 2: 6-7). ${ }^{86}$ Orang Papua merenungkan bahwa Allah dan sabda-Nya sudah ada di Papua sebelum Injil diwartakan misionaris. Yesus sudah ada di Papua berkat kebangkitan-Nya. Ia telah menjadi Yesus Ras-Melanesia. Misionaris bukan membawa Allah ke Papua, melainkan memberitakan kehadiran-Nya. Allah Bapa dengan pengantaraan Putra-Nya, telah berkarya di Tanah Papua dalam Roh Kudus sebelum Injil Kristus diwartakan di Bumi Cenderawasi. Dengan demikian, orang Papua dapat mengerti dan menghayati siapa itu Yesus dalam konteks dan budaya mereka sendiri. Ada pula beberapa pokok Kristologi
Papua bernuansa soteriologis untuk menghayati Sosok Yesus Sang Penyelamat. Beberapa di antaranya adalah: Yesus sebagai Peagabega, Yesus sebagai Nourekul, Yesus sebagai Koyeidaba, Yesus sebagai Mobubokouto (Sumber Kehidupan) dan Yesus sebagai Ipa Bokouto (Sang Pengasih). Gelargelar tersebut diungkapkan orang Papua karena pandangannya dalam kebudayaan mereka tentang konsep keselamatan. Orang Papua mengungkapkannya dalam liturgi dan doa Gereja.

Kristologi Papua bukan hanya terdapat dalam budaya dan liturgi, tetapi belajar dari Kristologi Asia dapat dipandang secara lebih holistik. Yesus perlu dilihat secara menyeluruh; Ia memegang peranan lebih sentral dalam seluruh pengalaman serta perjuangan hidup orang Papua, termasuk penderitaan yang mereka alami karena situasi dan kondisi politik saat ini. Yesus hadir di tengah mereka untuk menyelesaikan konflik dan membawa damai sejahtera di Tanah Papua, sebagaimana telah dibawa-Nya di tanah Israel (bdk. Yoh 14: 27).

Kristologi Papua sebenarnya bermaksud merumuskan jawaban iman orang Papua atas pertanyaan“Siapakah Aku ini?" Jawabannya dicari dalam konteks sekarang yang ditandai oleh kekerasan terhadap orang Papua dari pihak militer, oleh program transmigrasi yang membuat orang asli Papua menjadi minoritas di tanahnya sendiri, oleh pengrusakan hutan tropis dan pengusiran rakyat dari tanah adat mereka demi monokultur kelapa sawit, oleh pelanggaran hak asasi manusia dari pihak aparat "ke-(tidak)-amanan", dan masalah kemanusiaan lainnya. Oleh karena itu, dibutuhkan gagasan-gagasan kristologis yang relevan di Papua.

Beberapa gagasan kristologi Papua dapat dikembangkan berdasarkan konteks umum 
di atas, antara lain: Yesus Kristus"lahir" di Papua. Mengapa? Sabda dalam penciptaan dunia, penjelmaan menjadi manusia, kebangkitan Yesus serta pemuliahanNya, dan Yesus ada sebelum Abraham ada (Yoh 8: 58). Ia sudah ada di Papua, dan menjadi native Papuan sebelum manusia (Papua) diciptakan oleh Sang Pencipta. Dengan demikian, Yesus Kristus menjadi saudara, Ia sebagai Kakak Maha Besar orang Papua. Pertama-tama, Yesus berasal dari Bapa, Anak Sulung dan lebih utama dari segala yang diciptakan (bdk. Kol 1:13). Ia adalah Yang Pertama bangkit dari antara orang mati (Kol 1: 18). Yesus kelahiran Papua, adalah Kakak Pertama dan utama. Ia Kakak bagi suku-suku Papua dan Kakak pertama dan utama bagi orang Papua secara umum di pulau Cendrawasih ini. Ia memiliki sejumlah karakteristik sebagai peran sebagai Sang Kakak, sejak penciptaan dunia.

Dia menjadi Pembela kaum lemah. Yesus sebagai manusia Papua memiliki karakteristik Kakak dalam budaya-budaya orang Papua bahwa Ia dapat melindungi, menguatkan yang lemah dalam keluarga, klan, suku dan Papua pada umumnya. Dengan mengikuti catatan Phan dalam narasi teologis-kristologis Song bahwa Yesus dapat dilihat sebagai Figur yang membebaskan yang lemah dan menderita, Ia bersama kaum tersalib. Dalam konteks Papua secara umum, Ia menyuarakan kaum tak bersuara. Ia berpihak pada lemah/ fakir miskin (Luk 6: 20), akibat sejumlah problema dan menyerukan celaka kepada penguasa agar bertobat

Yesus sebagai Kakak memiliki jiwa pendamai. Ia adalah Sang Rekonsiliator. Oleh karena itu, sebagai Sang Kakak, Ia memiliki semangat damai dalam klan, suku dan kelompok-kelompok yang bertikai. Yesus sebagai Kakak dapat mendamaikan antara yang bermusuhan. Dengan Sifat ilahi Sang Kakak dapat mendamaikan problem besar Papua misalnya antar suku, Papua dan non Papua. Ekspresi Yesus yang diungkapkannya adalah"Kipo Moti” (salam Khas Suku Mee Papua).

Pribadi Yesus sebagai Kakak juga adalah Pembebas. Ia memiliki sifat Bapa-Nya untuk membebaskan semua problema yang membelenggu terutama dalam keluarga kecil maupun besar. Pribadi Yesus sebagai Kakak yang mengedepankan kebenaran sejati dapat membebaskan pada kemerdekaan sejati. Yesus Kristus datang bagi orang-orang yang tertindas, orang-orang yang dikuasai pada pembebasan.

Yesus juga sebagai Penyelamat. Seorang pribadi kakak adalah berusaha menghadirkan keselamatan. Yesus menghadirkan keselamatan kini dan kelak. Ia menghadirkan kebahagiaan, sukacita, damai sejahtera. Kristus adalah perintis keselamatan. Ia adalah sulung dari segala ciptaan. Ia ada terlebih dahulu dari segala sesuatu ada di dalam Dia (Kol 1: 17). Yesus Kristus adalah revolusioner dan tokoh yang dapat membebaskan orang Papua dari berbagai problem kehidupan ${ }^{87}$.

Di akhir tulisan ini, saya mengusulkan metode pengembangan Kristologi Papua: langkah pertama adalah merumuskan konteks, langka kedua adalah analisa atas konteks dari ilmu sosial-politik atau salah satu ilmu humaniora yang relevan, langkah ketika adalah refleksi iman dari Kitab Suci (Alkitabiah) dan Ajaran Gereja (dogmatik), dan langka kelima adalah sintesa teologis (dari penulis), dan langka keenam adalah tindak lanjut (pastoral). 


\section{CATATAN AKHIR}

1 Peter C. Phan, "Jesus Christ with the Asian Face," Theological Studies 57 (1996): 424.

2 Pendekatan ini terispirasi dari Kristologi Amerika Latin yang dikembangkan, misalnya L Boff: Yesus sebagai Sang Pembebas. Lih. M. Purwatma, Firman Menjadi Manusia, Refleksi Historis-Sistematis Mengenai Yesus Kristus dan Allah Tritunggal (Yogyakarta: Kanisius, 2015), 102

$3 \quad$ M. Purwatma, Firman Menjadi Manusia, Refleksi Historis-Sistematis Mengenai Yesus Kristus dan Allah Tritunggal, 102.

4 Aloysius Pieris, Berteologi dalam Konteks Asia, diterjemahkan dari An Asian Theology of Liberation oleh Agus M. Hardjana, (Yogyakarta: Kanisius, 1996), 83-87.

5 J.B. Banawiratma, SJ, Yesus Sang Guru, Pertemuan Kejawen dengan Injil, (Yogyakarta: Kanisius, 1977), 1011

$6 \quad$ Bdk. Yoh 1: 14. Lihat pula tulisan oleh Joe Gaquare, "Indigenization as Incarnation: the Concept of Melanesian Christ", dalam: Joseph Knoebel, SVD dkk. (eds.), Christ in Melanesia, Exploring Theological Issues, (Goroka, Papua New Guinea: Point, 1977), 147.

7 Peter C. Phan, "Jesus the Christ with an Asian Face", 430.

Pertanyaan serupa, dalam konteks konteks Asia, dikaji para teolog Asia, misalnya: Peter C. Phan, "Jesus the Christ with an Asian Face", 400 dan 430

9 Agus Alue Alua, Karakteristik Agama-Agama Melanesia, (Jayapura: Biro Penelitian STFT "Fajar Timur", Abepura, 2006), 9-10.

10 Agus Alue Alua, Karakteristik Agama-Agama Melanesia, 10

11 Neles Tebay, "Agama-Agama Asli Melanesia" dalam A. Eddy Kristyanto (ed.), Spiritualitas Dialog - Narasi Teologis tentang Kearifan Religius, (Yogyakarta: Kanisius, 2010), 27.

12 Agus Alue Alua, Karakteristik Agama-Agama Melanesia, 11.

13 Agus Alue Alua, Karakteristik Agama-Agama Melanesia, 11

14 Neles Tebay, "Agama-Agama Asli Melanesia”, 28.

15 Agus Alue Alua, Karakteristik Agama-Agama Melanesia, 15 .

16 Agus Alue Alua, Karakteristik Agama-Agama Melanesia, 17.

17 Neles Tebay, "Agama-Agama Asli Melanesia”, 31.

18 Agus Alue Alua, Karakteristik Agama-Agama Melanesia, 20

19 Agus Alue Alua, Karakteristik Agama-Agama Melanesia, 22

20 Agus Alue Alua, Karakteristik Agama-Agama Melanesia, 24

21 Neles Tebay, "Agama-Agama Asli Melanesia" 30-31.

22 Agus Alue Alua, Karakteristik Agama-Agama Melanesia, 27.

23 Neles Tebay, "Agama-Agama Asli Melanesia” 30.

24 Agus Alue Alua, Karakteristik Agama-Agama Melanesia, 29.

25 Neles Tebay, "Agama-Agama Asli Melanesia”, 33.

26 Agus Alue Alua, Karakteristik Agama-Agama Melanesia, 34.

27 Manfret Mote, S. Fil., Touye Pegangan Hidup Bersama, Gai, Dimi Gai dan Touye dalam Kehidupan Suku Mee Papua, (Jakarta Barat: Grogol, 2013), 34.

28 Manfret Mote, S. Fil., Touye Pegangan Hidup Bersama, Gai, Dimi Gai dan Touye dalam Kehidupan Suku Mee Papua, 35.
29 Neles Tebay, "Agama-Agama Asli Melanesia", 32

30 Frame of reference secara sederhana diterjemahkan sebagai kerangka acuan. Kerangka acuan yang dimaksud adalah nilai-nilai budaya yang diwariskan oleh nenek moyang orang Papua-Melanesia. Lih. Agus Alue Alua, Karakteristik Agama-Agama Melanesia, 2-3.

31 Misionaris (zendeling) Protestan di antaranya Pdt. Carl Ottow dan Pdt. John Geissler pertama kali menetap di Pulau Mansinam, sebuah pulau dekat Manokwari. Mereka kemudian menyebarkan Injil di wilayah utara Papua. Lih. P.J. Drooglever, Tindakan Pilihan Bebas! Orang Papua dan Penentuan Nasib Sendiri diterjemahkan dari Een Daad Van Vrije Keuze. De Papoea's van westelijk Niew-Guinea en de grenzen van het zelbeschkkingsrecht oleh Dr. Jan Riberu (Yogyakarta: Kanisius, 2010), 53.

32 Penyebaran agama Katolik bermula dari kepulauan Kei (Maluku) ke Merauke (Papua) oleh misionaris MSC tahun 1905. Mereka menyebarkan Injil dari Merauke ke daerah Boven Digul, Mappi, Agats-Asmat, Mimika, dan ke daerah pegunungan wilayah Paniai 1932. Namum perlu diketahui bahwa Pater Le Cocq d'Armandvville, SJ lebih dulu menyebarkan Injil tahun 1882 di Fak-Fak dan Mimika; ia telah membaptis 64 orang lokal. Pada April tahun 1895, Pater Le Cocq d'Armandville, SJ meninggal dunia karena ditelan ombak di Pantai sekitar Mimika dan Fak-Fak. Lih. P.J. Drooglever, Tindakan Pilihan Bebas! Orang Papua dan Penentuan Nasib Sendiri, 55-56.

33 Joe Gaquare, "Indigenization as Incarnation: the Concept of Melanesian Christ", 147.

34 Joe Gaquare, "Indigenization as Incarnation: the Concept of Melanesian Christ, 148.

35 Joe Gaquare, "Indigenization as Incarnation: the Concept of Melanesian Christ, 148.

36 Joe Gaquare, "Indigenization as Incarnation: the Concept of Melanesian Christ", 151.

37 Joe Gaquare, "Indigenization as Incarnation: the Concept of Melanesian Christ", 150.

38 Joe Gaquare, "Indigenization as Incarnation: the Concept of Melanesian Christ", 150.

39 Joe Gaquare, "Indigenization as Incarnation: the Concept of Melanesian Christ", 151

40 Joe Gaquare, "Indigenization as Incarnation: the Concept of Melanesian Christ", 150.

41 Anton Wessels, Memandang Yesus, Gambar Yesus dalam Berbagai Budaya, diterjemahkan dari Jezus Zien: Hoe Jezuz is Overgeleverd in Andere Cukuren, oleh Evie J., (Jakarta: BPK Gunung Mulia, 2001), 137-138.

42 M. Purwatma, mengungkapkan bahwa Kristologi terkait erat dengan soteriologi. Iman akan Yesus Kristus dirumuskan dalam konteks keselamatan, mula-mula ketika iman akan Yesus masuk di dunia Yunani. Lih. M. Purwatma, Pr., Firman Menjadi Manusia, Refleksi Historis-Sistematis Mengenai Yesus Kristus dan Allah Tritunggal, 15.

43 The fifth resources is Asian cultures in general, which are embodied in stories, myths, folklore, symbols, poetry, songs, visual art, and dance. The use of these cultural artifacts promises to add a very distinctive voice to Christian theology coming from the deepest yearnings of the people of Asia. Lih. Peter C. Phan, "Jesus the Christ with an Asian Face", 405.

44 Kleopas Sondegau, Mengimani Yesus Kristus melalui Tokoh Peagabega dalam Suku Migani, (Tesis Magister yang Tidak Dipublikasikan, Fakultas Teologi, Universitas Parayangan, Bandung, 2018), 91.

45 Kisah kehidupan lebih lengkap Peagabega dan analisanya dapat dilihat: Kleopas Sondegau, Mengimani Yesus 
Kristus melalui Tokoh Peagabega dalam Suku Migani, 59-66.

46 Kleopas Sondegau, Mengimani Yesus Kristus melalui Tokoh Peagabega dalam Suku Migani, 62.

47 Kleopas Sondegau, Mengimani Yesus Kristus melalui Tokoh Peagabega dalam Suku Migani, 60.

48 Kleopas Sondegau, Mengimani Yesus Kristus melalui Tokoh Peagabega dalam Suku Migani, 91-96.

49 Kleopas Sondegau, Mengimani Yesus Kristus melalui Tokoh Peagabega dalam Suku Migani, 60.

50 Markus Haluk, Aneka Gelar Yesus dalam Kitab Suci Perjanjian Baru dan Gereja Baliem, 21-23. Bdk. Theo Kossay, Menemukan Wajah Kristus dalam Budaya Papua, Konteks Budaya Orang Hubula terdapat dari https://www.kompasiana.com/theokossay/menemukan-wajah-kristus -dalam-budaya-papua_552fb1ef6ea834a01c8b4599, diakses pada, 6 Juni $201 \overline{8}$.

51 Markus Haluk, Aneka Gelar Yesus dalam Kitab Suci Perjanjian Baru dan Gereja Baliem 21-23. Bdk. Theo Kossay, Menemukan Wajah Kristus dalam Budaya Papua, Konteks Budaya Orang Hubula terdapat dari https://www.kompasiana.com/theokossay/menemukan-wajah-kristus -dalam-budaya-papua_552fb1ef6ea834a01c8b4599, diakses pada 6 Juni 2018.

52 Markus Haluk, Aneka Gelar Yesus dalam Kitab Suci Perjanjian Baru dan Gereja Baliem 29-30. Bdk. Theo Kossay, Menemukan Wajah Kristus dalam Budaya Papua, Konteks Budaya Orang Hubula tersedia dari https://www.kompasiana.com/theokossay/menemukan-wajah-kristus -dalam-budaya-papua_552fb1ef6ea834a01c8b4599, diakses pada, 6 Juni $201 \overline{8}$.

53 Markus Haluk, Aneka Gelar Yesus dalam Kitab Suci Perjanjian Baru dan Gereja Baliem, 34.

54 Markus Haluk, Aneka Gelar Yesus dalam Kitab Suci Perjanjian Baru dan Gereja Baliem, 29-30. Bdk. Theo Kossay, Menemukan Wajah Kristus dalam Budaya Papua, Konteks Budaya Orang Hubula tersedia dari https://www.kompasiana.com/theokossay/menemukan-wajah-kristus -dalam-budaya-papua_552fb1ef6ea834a01c8b4599, diakses pada, 6 Juni $201 \overline{8}$.

55 Kain dikenakan pula kepada panglima perang dalam suku Hubula, kepada pemimpin yang berhasil mengalahkan klan musuh. Namun menurut Haluk, refleksi Kristologi Huwulu tidak menyebutkan sosok Yesus yang dikenakan dalam konteks perang ini. Lih. Markus Haluk, Aneka Gelar Yesus dalam Kitab Suci Perjanjian Baru dan Gereja Baliem, 34.

56 Markus Haluk, Aneka Gelar Yesus dalam Kitab Suci Perjanjian Baru dan Gereja Baliem, 41.

57 Melkior N.N Sitokdana, S.Kom. M.Eng., Menerima Misionaris, Menjemput Peradaban (Yogyakarta: Kanisius, 2016), 54 dan 76.

58 Melkior N.N Sitokdana, Menerima Misionaris, Menjemput Peradaban, 78.

59 Titus Christ Pekey, Manusia Mee di Papua, (Yogyakarta: Galang Press, 2008), 25.

60 Misalnya: sebutan Kapauku, artinya orang di balik gunung; sebuah ungkapan dari suku Kamoro, Timika. Sebutan Ekagi adalah dari bahasa suku Moni, Intan Jaya, yang artinya penghormatan kepada laki-laki bernada sinis. Penyebutan dua nama itu dipakai oleh misionaris dan antropolog dalam tulisan mereka tentang suku Mee, misalnya oleh antropolog Leopold Pospisil dalam bukunya berjudul The Kapauku Papuans of West New Guinea.

61 Titus Christ Pekey, Manusia Mee di Papua, 81-98.

62 Neles Tebay, Menemukan Wajah Yesus dalam Budaya
Mee tersedia dari http://ofmdutadamai.wordpress. com/2012/08/19/menemukakan-wajah-kristus-dalam-budaya-mee/, diakses, 1 Desember 2016.

63 Yohanes Kayame, Yesus Kristus sebagai "Mobubokouto" dan "Ajibouto": suatu Refleksi Kristologi-Soteriologis atas Mitos Koyeidaba dalam Kepercayaan Suku Mee Papua, (Yogyakarta: Paper yang tidak dipublikasikan pada Fakultas Teologi Universitas Sanata Dharma, 2016), 3.

64 Yohanes Kayame, Yesus Kristus sebagai "Mobubokouto" dan "Ajibouto", 3.

65 Yohanes Kayame, Yesus Kristus sebagai "Mobubokouto" dan "Ajibouto", 4

66 Yohanes Kayame, Yesus Kristus sebagai "Mobubokouto" dan "Ajibouto", 5-6.

67 Manfret Mote S. Fil, dkk., Touye Pegangan Hidup Bersama, (Jakarta: Cermin Papua, 2013), 27-40.

68 Yohanes Kayame, Yesus Kristus sebagai "Mobubokouto" dan "Ajibouto", 7.

69 Neles Kebadabi Tebay, "Jesus as Iniuwai Ibo (The Great Elder Brother of Ours)”, 318; bdk., Fransiskus W. Doo, Integrasi Gelar-Gelar Yesus dalam Doa-Doa Kristen Mee, 51-52.

70 Manfret Mote S. Fil., Touye Pegangan Hidup Bersama, Gai, Dimi Gai dan Touye dalam Kehidupan Suku Mee Papua, 97-105; bdk., Fransiskus W. Doo, Integrasi Gelar-Gelar Yesus dalam Doa-Doa Kristen Mee, 52.

71 Neles Kebadabi Tebay, "Jesus as Iniuwai Ibo (The Great Elder Brother of Ours)", 321-322.

72 Neles Kebadabi Tebay, "Jesus as Iniuwai Ibo (The Great Elder Brother of Ours)", 317.

73 Fransiskus W. Doo, Integrasi Gelar-Gelar Yesus dalam Doa-Doa Kristen Mee, 37.

74 Fransiskus W. Doo, Integrasi Gelar-Gelar Yesus dalam Doa-Doa Kristen Mee, 38

75 Yohanes Kayame, Yesus Kristus sebagai "Mobubokouto" dan "Ajibouto", 6-7.

76 Adrianus Sunarko, Kristologi, Tinjauan HistorisSistimatis, (Jakarta: Obor, 2017), 168

77 Yohanes Kayame, Yesus Kristus sebagai "Mobubokouto" dan "Ajibouto", 8

78 Nota dalam bahasa suku Mee artinya ubi atau petatas. Nota adalah makanan utama suku Mee.

79 Yohanes Kayame, Yesus Kristus sebagai "Mobubokouto" dan "Ajibouto", 9

80 Neles Kebadabi Tebay, "Jesus as Iniuwai Ibo (The Great Elder Brother of Ours)", 320.

81 Peter C. Phan, "Jesus Christ with the Asian Face", 406410.

82 Peter C. Phan, "Jesus Christ with the Asian Face", 411416.

83 Peter C. Phan, "Jesus Christ with the Asian Face", 417421.

84 Peter C. Phan, "Jesus Christ with the Asian Face", 422 423.

85 Orang Papua, non Papua, semua orang di dunia, semuanya adalah umat-Ku, sabda Yesus. Lih. Neles Kebadabi Tebay, "Jesus as Iniuwai Ibo (The Great Elder Brother of Ours)", 320.

86 Joe Gaquare, "Indigenization as Incarnation: the Concept of Melanesian Christ”, 147.

87 Yohanes Kayame, Yesus Kristus dalam Wajah Papua Kajian Kristologi Asia Peter C Phan untuk Konteks Papua, (Tesis Magister Teologi yang tidak dipublikasikan Fakultas Teologi Universitas Sanata Dharma, Yogyakarta, 2019), 211-273. 


\section{DAFTAR RUJUKAN}

Alua, Agus A. Karakteristik Agama-Agama Melanesia. Abepura: Biro Penelitihan STFT "Fajar Timur”, 2006.

Banawiratma, J.B, SJ. Yesus Sang Guru, Pertemuan Kejawen dengan Injil. Yogyakarta: Kanisius, 1977.

Boelaars, Jan. Manusia Irian, Dahulu, Sekarang dan Masa Depan. Jakarta: PT Gramedia, 1986.

Boff, Leonardo. Yesus Kristus Pembebas. Diterjemahkan dari Jesus Christus der Befreier oleh Aleksius. Maumere: LPBAJ, Cet. keII, 2000 .

Darmawijaya, St. Gelar-Gelar Yesus. Yogyakarta: Kanisius, 1987.

Doo, Fransiskus. Integrasi Gelar-Gelar Yesus dalam Doa-Doa Kristen Mee Tinjauan Kristologis-Antropologis. Abepura: STFT "Fajar Timur", 2005.

Drooglever, P.J. Tindakan Pilihan Bebas! Orang Papua dan Penentuan Nasib Sendiri. Diterjemahkan dari Een Daad Van Vrije Keuze. De Papoea's van westelijk Niew-Guinea en de grenzen van het zelbeschkkingsrecht oleh Dr. Jan Riberu. Yogyakarta: Kanisius, 2010 .

Gaqurae, Joe. "Indigenization as Incarnation: the Concept of Melanesian Christ", dalam Joseph Knoebel, SVD dkk., (eds.), Christ in Melanesia, Exploring Theological Issues. Goroka, Papua New Guinea: Point, 1977, 146-152.

Haluk, Markus. Aneka Gelar Yesus dalam Kitab Suci Perjanjian Baru dan dalam Gereja Baliem, Upaya Memahami Kristologi Lokal dalam Konteks Gereja di Baliem, Wamena. Abepura: STFT “Fajar Timur”, 2005.

Kayame, Yohanes. Yesus Kristus dalam Wajah Papua, Kajian Kristologi Asia Peter C Phan untuk Konteks Papua. Tesis Magister Teologi yang tidak dipublikasikan. Fakultas Teologi Universitas Sanata Dharma, Yogyakarta, 2019.

Kayame, Yohanes. Yesus sebagai "Mobubokouto" dan "Ajibokouto": Suatu Refleksi Kristologi-Soteriologis atas Tokoh "Koyeidaba" dalam Kepercayaan Suku Mee Papua. Paper Kristologi Kontekstual yang tidak dipublikasikan. Program Studi Magister Teologi,
Fakultas Teologi Universitas Sanata Dharma, Yogyakarta, 2016.

Kossay, Theo. Menemukan Wajah Kristus dalam Budaya Papua, Konteks Budaya Orang Hubula"; tersedia dari https://www.kompasiana. com/theokossay /menemukan-wajah-kristus-dalam-budaya-papua_552fb1ef6ea834a01c8b4599. Diakses, 06 Juni 2018.

Pekey, Titus Christ. Manusia Mee di Papua. Yogyakarta: Galang Press, 2008.

Phan, Peter C. "Jesus Christ with the Asian Face", dalam Theological Studies 57 (1996): 399-430.

Purwatma, M., Firman Menjadi Manusia, Refleksi Historis-Sistematis Mengenai Yesus Kristus dan Allah Tritunggal. Yogyakarta: Kanisius, 2015.

Sitokdana, Melkior. Menerima Misionaris, Menjemput Peradaban. Yogyakarta: Kanisius, 2016.

Sondegau, Kleopas. Mengimani Yesus Kristus melalui Tokoh Peagabega dalam Suku Migani-Papua. Tesis Magister yang Tidak Dipublikasikan. Fakultas Teologi, Universitas Parayangan, Bandung, 2018.

Sunarko, Adrianus, Kristologi, Tinjauan Historis-Sistimatis. Jakarta: Obor, 2017.

Tebay, Neles. "Jesus as Iniuwaiibo (The Great Elder Brother of Ours), Christology Expressed in the Hyms of Mee Christians of Papua”, dalam: Exchange 29 (2000): 313314.

Tebay, Neles. "Agama-Agama Asli Melanesia" dalam A. Eddy Kristyanto (ed.), Spiritualitas Dialog - Narasi Teologis tentang Kearifan Religius. Yogyakarta: Kanisius, 2010, 2535 .

Tebay, Neles. "Menemukan Wajah Yesus dalam Budaya Mee". Tersedia dari http://ofmdutadamai.wordpress.com/2012/08/19/ menemukakan-wajah-kristus-dalam-budaya-mee/. Diakses, 01 Desember 2016.

Wessels, Anton. Memandang Yesus, Gambar Yesus dalam Berbagai Budaya. Diterjemahkan dari Jezus Zien: Hoe Jezuz is Overgeleverd in Andere Cukuren, oleh Evie J. Jakarta: BPK Gunung Mulia, 2001. 
